\title{
Efeitos da suplementação da dieta com linhaça nos sintomas climatéricos de mulheres na pós-menopausa
}

Renée Leão Simbalista

Tese apresentada ao Programa de PósGraduação em Saúde Pública para obtenção do título de Doutor em Saúde Pública.

Área de Concentração: Nutrição

Orientador: Prof. Dr. José Alfredo Gomes Arêas

Co-orientador: Prof. Dr. José Mendes Aldrighi

São Paulo 2007

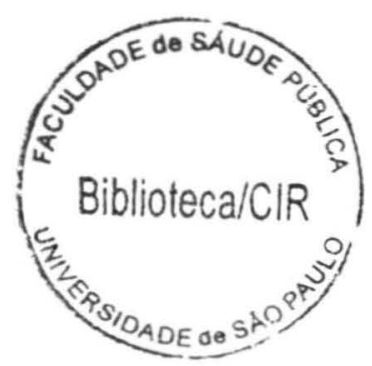


É expressamente proibida a comercialização deste documento, tanto na sua forma impressa como eletrônica. Sua reprodução total ou parcial é permitida exclusivamente para fins acadêmicos e científicos, desde que na reprodução figure a identificação do autor, título, instituição e ano da tese.

$$
4831612007 \text { doc }
$$


SIMBALISTA, R. L. Efeitos da suplementação da dieta com linhaça nos sintomas climatéricos de mulheres na pós-menopausa. 2006. 110 p. Tese (Doutorado em Saúde Pública) - Faculdade de Saúde Pública, USP, São Paulo.

Objetivo: Avaliar os efeitos do consumo diário de um pão enriquecido com farinha de linhaça, rico em lignanas, sobre os sintomas climatéricos e espessura endometrial de mulheres na pós-menopausa. Métodos: Na primeira fase foram desenvolvidos dois tipos de pães isocalóricos, com aparência similar. Um rico em lignanas, a partir da farinha de linhaça desengordurada e, o segundo, controle. Foram realizados testes para verificar a estabilidade dos ácidos graxos e das lignanas no produto de estudo. $\mathrm{Na}$ segunda etapa foi realizado um ensaio clínico duplo-cego, randomizado, com controle placebo. Trinta e oito mulheres, na menopausa de 1 a 10 anos, com sintomas climatéricos de moderados a severos, sem medicação, foram divididas em 2 grupos e ingeriram durante 3 meses os produtos desenvolvidos. Análises das lignanas vegetais mostraram sua estabilidade ao processamento, de forma que uma porção diária de $80 \mathrm{~g}$ do pão estudado fornecia o equivalente a $25 \mathrm{~g}$ de semente de linhaça integral e 46 mg de lignanas. As variáveis de desfecho avaliadas foram o número diário de ondas de calor, o Índice Menopausal de Kupperman e a espessura endometrial. Para controle foram avaliados o perfil lipídico e hormônios (estradiol, FSH, TSH, T 4 livre) no plasma. A suplementação da dieta com os pães foi avaliada através de 2 recordatórios de 24 horas no pré e pós-tratamento. Resultados: Vinte pacientes no grupo de estudo e 18 no controle completaram o estudo. Nenhuma diferença estatisticamente significativa foi observada entre as características gerais das pacientes no momento inicial do estudo. Os dois grupos apresentaram redução estatística significativa nas ondas de calor e no IMK após 3 meses de tratamento, mas nenhuma diferença pôde ser verificada entre eles. Conclusões. Verificou-se que as lignanas vegetais são bastante estáveis ao processamento térmico e armazenagem sob refrigeração. Apesar da farinha de linhaça ter se mostrado uma boa alternativa para enriquecer produtos de panificação, por ser excelente fonte de fibras, ômega 3 e lignanas, a administração de $46 \mathrm{mg} /$ dia lignanas na forma de pães não foi mais efetiva que o placebo na redução do número ondas de calor, IMK e na espessura endometrial de mulheres na pós-menopausa que participaram do estudo.

Descritores: alimentos funcionais, fitoestrógenos, linhaça, lignanas, menopausa. 


\section{APRESENTAÇÃO}


A presente tese de doutorado em Saúde Pública foi desenvolvida junto ao Departamento de Nutrição da Faculdade de Saúde Pública da Universidade de São Paulo, em parceria com o Departamento de Saúde Materno-Infantil da mesma.

Esta dissertação teve como orientador o Professor Doutor José Alfredo Gomes Arêas e, como co-orientador, o Professor José Mendes Aldrighi, tendo sido desenvolvida no período de março de 2003 a dezembro de 2006.

Este volume está dividido em cinco capítulos: (1) Projeto e revisão de literatura; (2) caracterização da semente de linhaça nacional e estabilidade dos ácidos graxos ao processamento; (3) análise e estabilidade das lignanas na linhaça; (4).desenvolvimento dos pães: linhaça e controle; (5) Estudo Randomizado e Controlado dos Efeitos de Pães de Linhaça sobre os Sintomas Climatéricos de Mulheres na Pós-menopausa 


\section{AGRADECIMENTOS}


Ao meu orientador José Alfredo Gomes Arêas, pelo total apoio, incentivo e orientação, indispensáveis para realização deste projeto.

Ao meu co-orientador José Mendes Aldrighi, por abrir as portas da Casa do Climatério, local onde foi realizado este estudo, pela orientação e apoio.

À Prof. Lílian Thompson, pela oportunidade de estágio, por todo aprendizado, apoio e carinho.

À todos os componentes da banca de defesa e qualificação pela leitura e sugestões que enriqueceram esta tese.

À minha família, por todo amor, apoio e carinho incondicionais, principalmente aos meus pais que tiveram participação direta nesta tese, pela total empolgação em todas as etapas, inclusive nas correções. Em especial a minha mãe, por ser fonte inspiradora e razão para realização deste estudo.

À todas aquelas pessoas que além da imensa ajuda na execução deste trabalho se tornaram bons amigos. Em especial à Thais por todo carinho e paciência desde o início, mas principalmente como "desorientadora" nesta fase final.

À todas as mulheres que participaram deste estudo, pela disponibilidade, atenção e dedicação.

À gerente do estudo Rosana Soares, por todo profissionalismo, paciência e ajuda.

Aos meus colegas de curso e do laboratório.

A todos os funcionários e amigos do Departamento de Nutrição, muito obrigada pela ajuda, paciência e carinho. 
A Casa do Climatério / Fundação Zerbini pela oportunidade de realização deste estudo e pelos excelentes profissionais que participaram de toda fase do ensaio clínico: Dr. Vitor, Dr. Sergio, Dra. Claudiane, Dr. Israel, Dr. Bernardo, Juliana, Gilmara e Fátima.

Ao Instituto de Radiologia da FM/USP, pela parceria na realização dos exames de imagem, em especial ao Dr. Sergio Kobayashi responsável pela realização de todos os exames, por sua atenção, cordialidade e profissionalismo.

A Divisão de Laboratório Central do HC/USP, pela parceria na realização dos exames de sangue, em especial a funcionária Luciane.

Ao Sindicato da Indústria da Panificação e ao FUNDIPAN, pelo espaço e materiais cedidos para produção dos pães desenvolvidos e aos profissionais que muito me ensinaram e apoiaram: Dr. Paulo Schiamarelli, Eng. Cecília, Zezinho, André, Brunet, Fabio, Olaíde, Luciane, Giselle.

À Pazze Indústria e Comércio, por fornecer as amostras de farinha de linhaça utilizadas neste estudo.

A FAPESP, péla concessão da bolsa de estudos e por dispor de recursos financeiros para realização deste projeto. 


\section{ÍNDICE}




\section{ÍNDICE}

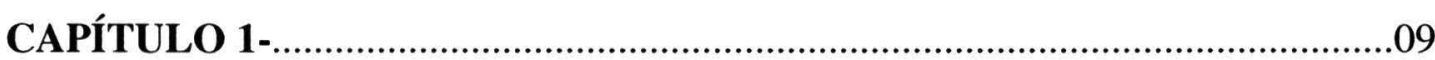

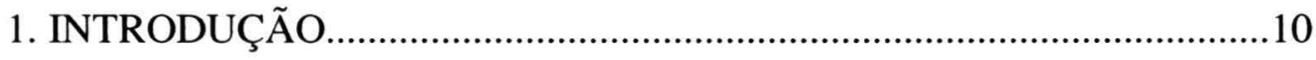

2. REVISÃO DA LITERATURA.................................................................

2.1. SEMENTE DE LINHAÇA...........................................................14

2.2. LIGNANAS ........................................................................17

2.2.1. Biodisponibilidade de lignanas.......................................19

2.3. MENOPAUSA.........................................................................

2.4. LINHAÇA E MENOPAUSA - estudos clínicos...........................26

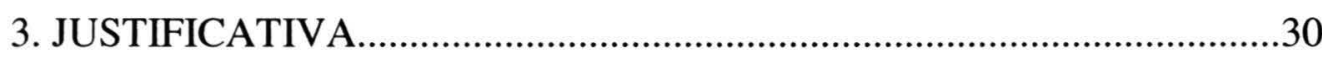

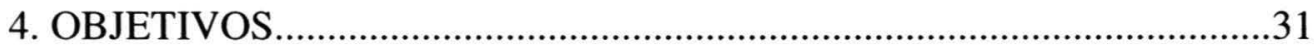

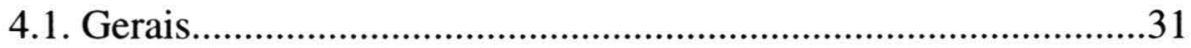

4.2. Específicos................................................................................

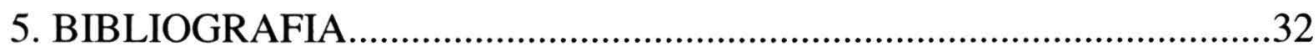

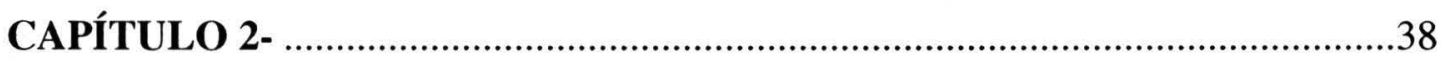

CARACTERIZAÇ̃̃o DA SEMENTE DE LINHAÇA NACIONAL E ESTABILIDADE DOS ÁCIDOS GRAXOS AO PROCESSAMENTO..............................................................

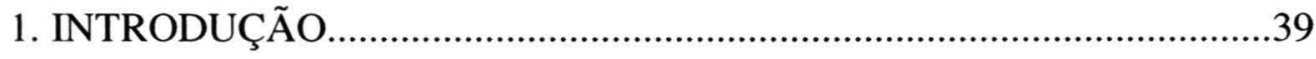

2. MATERIAL E MÉTODOS.......................................................................41

2.1. MATERIAL ...........................................................................

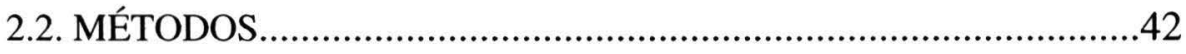

2.2.1. Composição Centesimal......................................................42

2.2.2. Perfil de Ácidos Graxos......................................................42

2.2.3. Avaliação da Oxidação Lipídica pelo método de TBA. ......44

3. RESULTADOS E DISCUSS ÃO...................................................................4

3.1. COMPOSIÇÃO CENTESIMAL..................................................4

3.2. PERFIL DE ÁCIDOS GRAXOS....................................................

3.3. AVALIAÇÃO DA OXIDAÇÃO LIPÍDICA....................................50

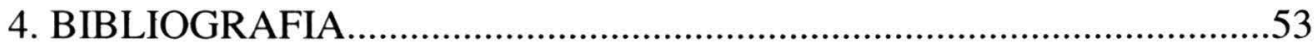


CAPÍtUlo 3. .55

ANÁLISE E ESTABILIDADE DAS LIGNANAS NA LINHAÇA........................................56

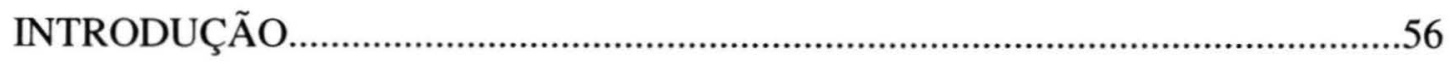

1.1. ANÁLISE DE LIGNANAS MAMÍFERAS.......................................58

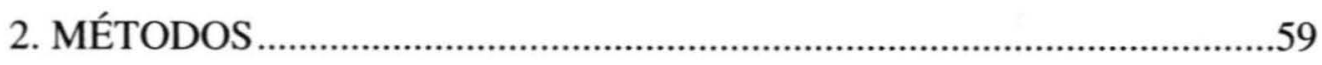

2.1. ANÁLISE DE LIGNANAS EM ALIMENTOS POR CG-MS.............59

3. RESULTADOS E DISCUSSÃO ….............................................................62

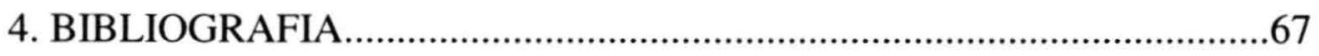

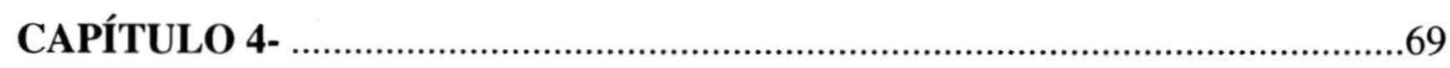

DESENVOLVIMENTO DOS PÃES - LINHAÇA E PLACEBO............................................70

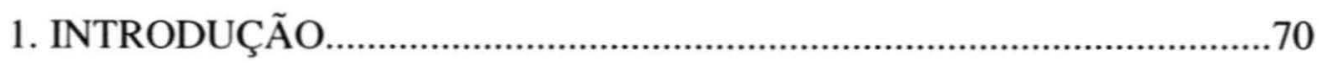

2. MATERIAL E MÉTODOS......................................................................72

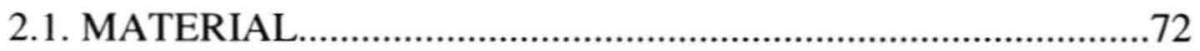

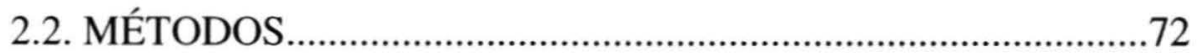

2.2.1. Análises Físicas...........................................................74

2.2.2. Análises Químicas.......................................................74

3. RESULTADOS E DISCUSSÃO.............................................................75

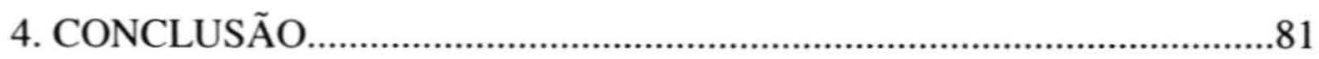

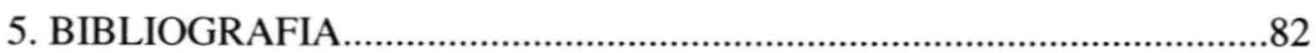

CAPÍTULO 5 -

ESTUDO RANDOMIZADO E CONTROLADO DOS EFEITOS DE PÃES DE LINHAÇA SOBRE OS SINTOMAS CLIMATÉRICOS DE MULHERES NA PÓS-

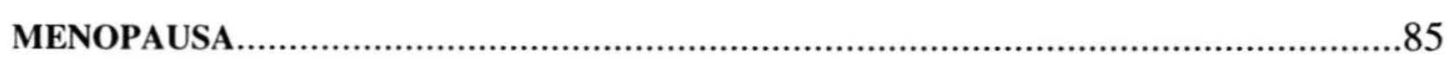

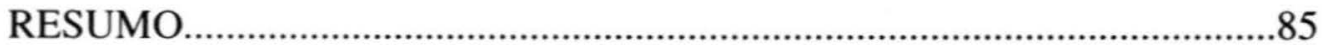

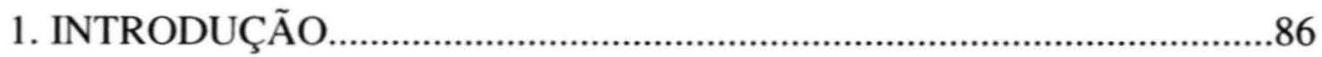

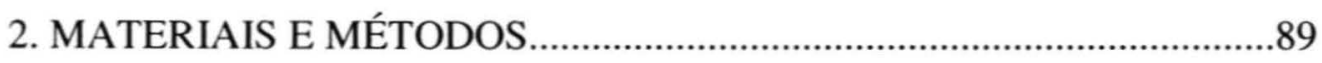

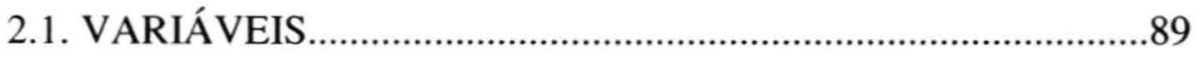

2.2. POPULAÇÃO

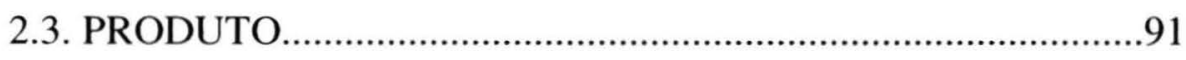

2.4.INTERVENÇÃO E RANDOMIZAÇÃO...................................92

2.5. ANÁLISES ESTATÍSTICAS.......................................................93 


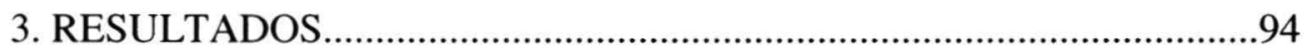

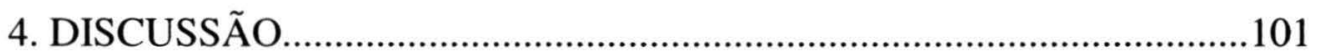

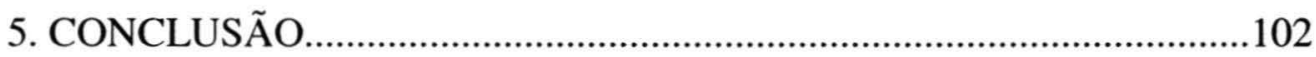

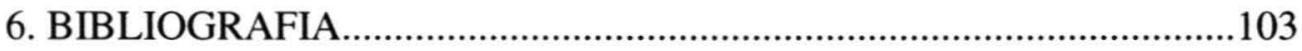

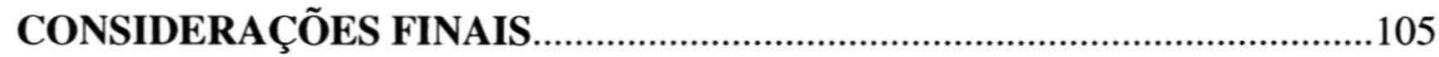
ANEXOS

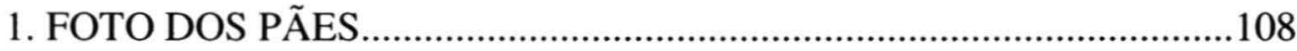

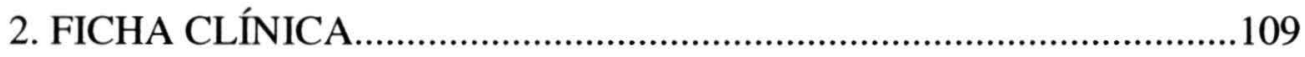




\section{CAPÍtulo 1}




\section{INTRODUÇÃO}

Os alimentos funcionais são aqueles, que, além da sua função básica de nutrir, podem trazer benefícios à saúde, seja através das características normais de sua composição, ou pela adição de outros componentes naturais com demonstrados efeitos metabólicos ou fisiológicos úteis na manutenção da boa saúde física e mental, podendo auxiliar na redução de riscos para doenças crônico-degenerativas. Este conceito evoluiu no Japão na década de 80 , através de um programa do governo que visava estimular o desenvolvimento de alimentos saudáveis, com propriedades medicinais, face ao envelhecimento da população (ARABBI, 2001).

Este segmento vem crescendo rapidamente dentro da indústria de alimentos, num mercado estimado em mais de US\$ 70 bilhões de dólares em todo mundo e segundo a Associação Brasileira das Indústrias de Alimentos (ABIA), nos últimos cinco anos, houve um aumento de $20 \%$ ao ano no consumo de alimentos funcionais no Brasil. Estima-se que este mercado tenha movimentado em 2005 cerca de US\$ 600 milhões no país, refletindo a mudança de comportamento da população que, mais informada, passou a reconhecer melhor a relação nutrição-saúde-doença (BIANCO, 2000).

Desde a antiguidade, sabe-se que certas enfermidades podem ser melhoradas por modificações alimentares, entretanto, é importante notar que nossos hábitos alimentares foram se modificando ao longo do tempo, com o surgimento de novas possibilidades associadas ao estilo de vida. A industrialização dos alimentos, por um lado, permitiu o aumento da oferta e maior facilidade de armazenamento e conservação, por outro, estimulou uma dieta rica em gorduras (particularmente as 
saturadas e hidrogenadas), açúcares e alimentos refinados e reduzida em carboidratos complexos, fibras e vitaminas. Esta dieta denominada "dieta ocidental", freqüentemente associada a um declínio progressivo da atividade física, trouxe inúmeros problemas de Saúde Pública, dentre eles o aumento da obesidade e da prevalência de doenças crônico-degenerativas - incluindo diabetes, doenças cardiovasculares, hipertensão e alguns tipos de câncer (WHO, 2004).

Desde 2002 a Organização Mundial da Saúde (WHO) divulgou a estratégia global para alimentação, atividade física e saúde, endossada em 2004, que estimula o desenvolvimento de pesquisas multidisciplinares que levem a um melhor conhecimento dos nossos alimentos e à compreensão científica de como seus componentes modulam processos biológicos envolvidos com a saúde ou doença. (WHO, 2002, 2004).

Neste âmbito, diversas pesquisas (CHÁVEZ-JAUREGUI et. al., 2000; CARDOSO-SANTIAGO et al., 2001; MOREIRA-ARAÚJO et al., 2002; BOMBO, 2006; MENDONÇA, 2006) vêm sendo desenvolvidas no Departamento de Nutrição, da Faculdade de Saúde Pública da USP, com o objetivo de identificar os benefícios nutricionais e funcionais de fontes alternativas de matérias-primas e incorporá-las ao desenvolvimento de produtos tradicionalmente consumidos pela população. Dados epidemiológicos relacionando dieta e doenças crônicas vêm estimulando pesquisas de intervenções preventivas. No entanto, muitos estudos ainda precisam ser realizados para que os alimentos funcionais tenham seus benefícios comprovados e possam apresentar em seu rótulo alegações de saúde, o que requer investimentos em pesquisas básicas e clínicas destes alimentos, para que eles possam ser utilizados 
suprindo carências ou auxiliando na diminuição de riscos para determinadas doenças (BRASIL $\left.{ }^{\mathrm{a}, \mathrm{b}}, 1999\right)$.

Com o aumento da expectativa de vida das mulheres e com a maior divulgação de pesquisas na área de saúde, a procura por terapias alternativas vem crescendo muito nos últimos anos, principalmente, na fase do climatério, em que ocorrem alterações significativas na sua qualidade de vida. Desta forma, torna-se importante o estudo dos efeitos de substâncias biologicamente ativas nos alimentos, como os fitoestrógenos, de forma a proteger e informar esta população ávida por tratamentos "naturais".

Os fitoestrógenos são substâncias que ocorrem naturalmente nas plantas e que possuem uma estrutura de anéis difenólicos que se assemelham ao 17-ß-estradiol (HUTCHINS et al., 2001). Entre os principais tipos de fitoestrógenos estão as lignanas e as isoflavonas, encontradas em abundância na linhaça e na soja, respectivamente. Alguns estudos sugerem que dietas ricas nestes compostos estariam associadas a menor incidência de ondas de calor, osteoporose e alguns tipos de câncer (ADLERCREUTZ et al., 2002).

A semente de linhaça possui de 75 a 800 vezes mais lignanas vegetais do que qualquer outro alimento (THOMPSON et al., 1999), o que a torna um ótimo modelo para verificar os efeitos deste fitoestrógeno sobre os sintomas climatéricos de mulheres na pós-menopausa.

Apesar de diversas pesquisas internacionais divulgarem os benefícios do consumo de linhaça à saúde (THOMPSON e CUNNANE; 2003), no Brasil, até o momento, muito pouco foi pesquisado e divulgado sobre o assunto. A pesquisa de fontes alternativas de matéria-prima, como a linhaça, é importante não somente pelo 
apelo nutricional, mas também pela possibilidade de divulgar e, conseqüentemente, estimular sua produção que já foi muito maior no país, ajudando a diminuir a dependência daquelas matérias-primas, que possuem um grande poder regulador sobre o mercado, como o trigo.

Desta forma, o presente trabalho propõe o desenvolvimento de um produto à base de farinha de linhaça, rico em lignanas, e o estudo da estabilidade de seus componentes nutricionais durante o processamento e armazenagem, para posterior estudo clínico em pacientes saudáveis na pós-menopausa, que apresentem ondas de calor, na tentativa de identificar os possíveis benefícios deste composto. 


\section{REVISÃO DE LITERATURA}

\subsection{SEMENTE DE LINHAÇA}

A linhaça é uma semente oleaginosa, proveniente da planta linho (Linum usitatissimum L.), muito consumida antes da Revolução Industrial. No entanto, devido à sua limitada vida-de-prateleira, foi praticamente banida da dieta, a partir da metade do século passado, voltando a ganhar atenção no início dos anos 90 , com a divulgação de seus benefícios nutricionais (DEMARK-WAHNEFRIED et al., 2001).

O maior produtor mundial é o Canadá, que detém cerca de 1/3 do mercado mundial, que gira em torno de 2,5 milhões de toneladas (DAUN et al., 2003). A rápida oxidação do óleo, devido ao seu alto conteúdo de ácidos graxos poliinsaturados, como o $\alpha$-linolênico, faz com que seja bastante utilizado para produção de esmaltes, vernizes e tintas. Suas fibras, obtidas dos talos da planta, possuem propriedades únicas para uso na produção de tecidos e papéis e durante muitos anos foi cultivada, principalmente, para produção do linho, sendo as sementes processadas como sub-produto. No entanto, recentemente, seu consumo alimentar voltou a crescer significantemente, passando a ser incorporada na produção de pães, muffins, entre outros (GROWER, 2002).

No Brasil, o principal cultivo de linhaça é mantido em Guarani das Missões, no noroeste gaúcho, por descendentes de imigrantes poloneses. Lavouras de linho já foram cultivadas no Brasil para a extração de fibras para uso têxtil (Linho), chegando a ocupar, na década de 60, uma área de 50 mil hectares, reduzida para 650 hectares, na década de 90. A indústria têxtil, a maior compradora na década de 60 , hoje importa da França e da Bélgica, devido à qualidade e ao tamanho das fibras 
produzidas nestes países. Ultimamente, sua produção voltou a crescer pela demanda das sementes e, em 2005, sua produção chegou a mais de 18 mil hectares. Além da demanda crescente, a produção foi impulsionada pela queda nos preços de culturas tradicionais, como o trigo (O LINHO, 2000; ZERO HORA, 2005).

A semeadura é feita nos meses de junho e julho e a colheita, de outubro a novembro, o que permite que, com a mecanização, seja possível plantar e colher a linhaça antes do plantio da soja, que ocorre em novembro, sendo uma boa alternativa para entressafra (O LINHO, 2000).

Com a divulgação de pesquisas e de seus benefícios nutricionais, espera-se que a produção supere rapidamente os patamares da década de 60 , fazendo com que, em outras regiões, a linhaça possa ser plantada como cultura alternativa durante a entressafra de outras culturas.

A semente é composta por aproximadamente $40 \%$ de óleo, $30 \%$ de fibra dietética, $20 \%$ de proteínas, $4 \%$ de cinzas e $6 \%$ de umidade. Estes valores podem variar com a amostra analisada e a metodologia empregada (DAUN et al., 2003).

A linhaça possui três componentes ativos de interesse à saúde: 1) alto conteúdo do ácido graxo $\alpha$-linolênico ( $>50 \%$ do total de ácidos graxos); 2) ser a maior fonte alimentar de lignanas vegetais e 3) possuir alta porcentagem de fibras dietéticas solúveis e insolúveis (THOMPSON $\left.{ }^{\mathrm{b}}, 2003\right)$

Sementes de linhaça são a maior fonte vegetal de ômega 3 (ALA), um ácido graxo essencial, normalmente presente em peixes de águas geladas e que é normalmente deficiente na "dieta ocidental". Algumas pesquisas relatam seu papel protetor sobre alguns tipos de câncer e doenças cardiovasculares, bem como os riscos 
associados à sua deficiência, o que levou a uma crescente demanda por produtos enriquecidos com ômega 3 nos últimos anos (HASLER, 1998).

Além disto, a linhaça é a mais rica fonte de lignanas, uma das principais classes de fitoestrogênios (THOMPSON et al., 1991). Nas plantas, os principais tipos são matairesinol e secoisolaraiciresinol (SDG), que, para serem absorvidos, precisam ser metabolizados pela flora bacteriana intestinal em enterodiol e enterolactona (NESBITT et al., 1999). Estes compostos difenólicos possuem estrutura similar ao estradiol, podendo apresentar atividade estrogênica fraca ou anti-estrogênica dependendo de fatores como: sua concentração, concentração de endógena de estradiol, características individuais do paciente e dos órgãos envolvidos (ADLERCREUTZ et al., 1993; HUTCHINS et al., 2000).

O terceiro componente, a fibra, estaria associado às lignanas presentes na parte externa da semente. O alto teor de fibras solúveis é interessante do ponto de vista nutricional, por ajudar a regular a resposta glicêmica e auxiliar na redução do colesterol (CUNNANE et al., 1995; RICKARD e THOMPSON., 1997), mas dificulta seu processamento, devido a formação de uma mucilagem no contato com a água. Esta mucilagem pode ser utilizada como goma, devido as suas propriedades espessantes e de emulsão (DAUN et al., 2003).

A linhaça também apresenta alguns fatores antinutricionais, como glicosídeos cianogênicos (linustatina) e ácido fítico, mas em dosagens baixas, que são eliminados durante processamento térmico, sendo recomendada sua utilização em produtos de panificação e confeitaria. Seu consumo na forma in natura de até $60 \mathrm{~g} / \mathrm{dia}$ (cerca de 3 colheres de sopa) não são prejudiciais a indivíduos sadios (OOMAH et al., 1992; DAUN et al., 2003). 


\subsection{LIGNANAS}

As lignanas vegetais são compostos fenólicos, compostos pela estrutura 2,3dibenzilbutano. Algumas podem ser metabolizadas em lignanas mamíferas, enterodiol (ED) e enterolactona (EL), através da flora bacteriana intestinal. Estes compostos possuem estrutura e peso molecular similares ao 17-ß-estradiol e foram identificados pela primeira vez na urina de mulheres e macacos em 1980, por dois grupos independentes (SETCHELL et al., 1980; STITCH et al., 1980).

Estudos subseqüentes revelaram que as lignanas de mamíferos encontradas eram derivadas de plantas e formadas no intestino grosso, passando pela circulação enteropática, assim como ocorre com os hormônios esteróides endógenos (AXELSON et al., 1982; SETCHELL et al., 1981).

Os fitoestrógenos são compostos que possuem atividade estrogência fraca ou antiestrogência e estrutura química que se assemelha ao estradiol, mas que tem origem nas plantas. Sua estrutura com anel difenólico, característica comum a todos estes compostos, assim como a distância entre seus grupos hidroxílicos (Figura 1), foi descrita por alguns pesquisadores (HUTCHINS et al., 2001).

A pesquisa destes compostos passou a ser de grande interesse nos últimos anos, porque alguns estudos sugerem sua ação protetora contra algumas doenças crônicas, como câncer, doenças cardiovasculares e diabetes (THOMPSON ${ }^{\mathrm{a}}, 2003$; PRASAD $\left.^{\mathrm{a}, \mathrm{b}}, 2003\right)$. Apesar de serem encontradas em muitos grãos e cereais, a semente de linhaça é a maior fonte de lignanas (THOMPSON et al., 1991). O aumento no seu consumo e seus beneficios à saúde podem ser, em parte, atribuídos a este composto. No entanto, novos estudos precisam ser desenvolvidos para que se 
possa estabelecer os níveis ótimos e a frequência de consumo da semente e das lignanas para que produzam benefícios à saúde.
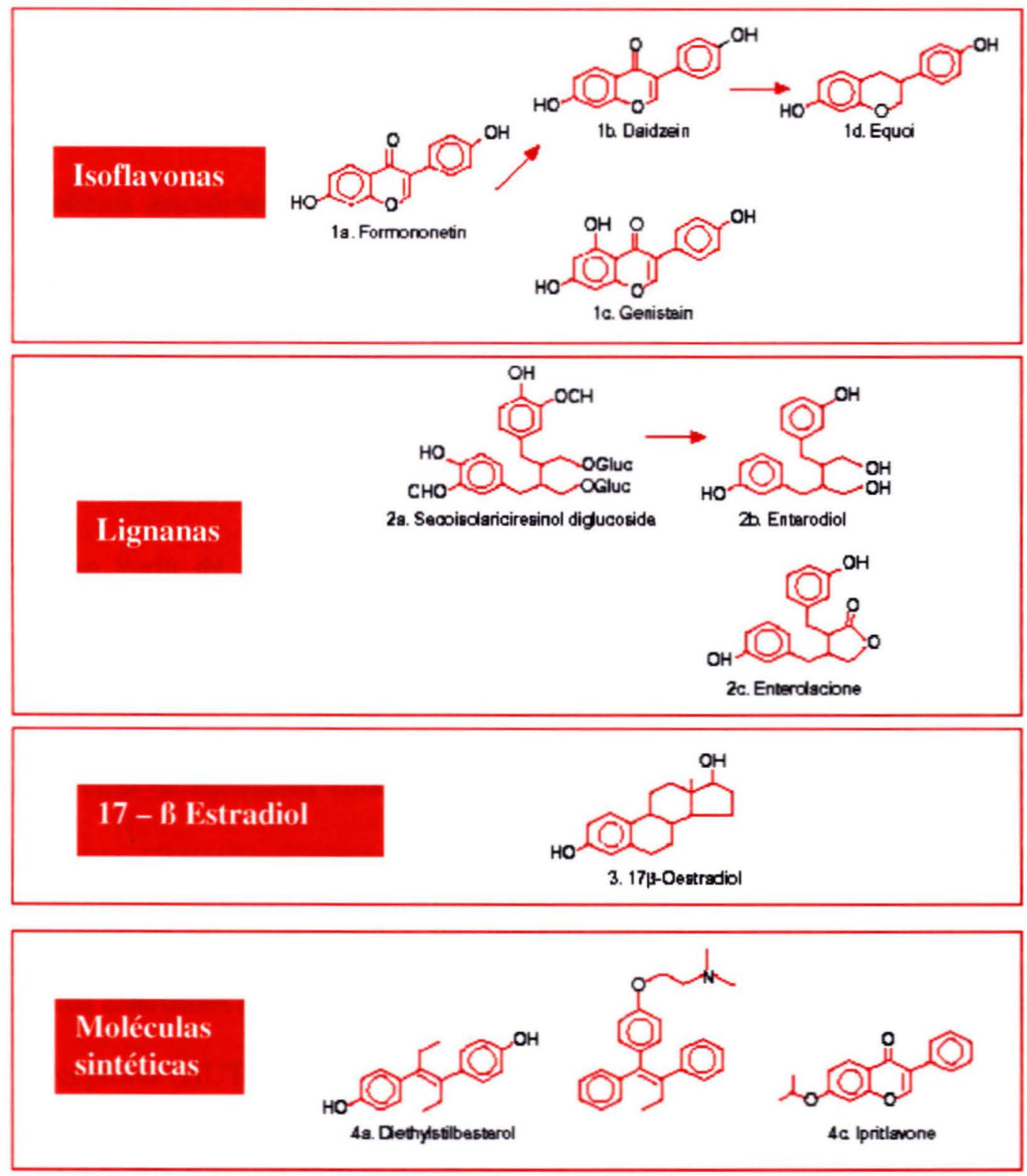

Figura 1. Estrutura química das isoflavonas, lignanas, estradiol e substâncias sintéticas. 
O problema é que faltam informações sobre a biodisponibilidade das lignanas, incluindo absorção, distribuição, metabolismo e excreção devido à dificuldade de se avaliar os níveis ingeridos deste composto e sua disposição no corpo e tecidos (THOMPSON $\left.{ }^{\mathrm{a}}, 2003\right)$.

Apesar de estudos epidemiológicos, in vitro e in vivo sugerirem que a suplementeção com lignanas, ou linhaça, pode influenciar a concentração endógena de hormônios esteróides, os poucos estudos clínicos realizados com humanos não chegaram a uma conclusão definitiva. A extensão das atividades estrogênica e antiestrogênica demonstrada em humanos irá depender da concentração endógena de hormônios que são biologicamente mais ativos (HUTCHINS e SLAVIN, 2003).

Os níveis séricos médios de estrogênios e androgênios em mulheres na prémenopausa varia de 25 a $100 \mu \mathrm{g} /$ dia. Esta média cai para 5 a $10 \mu \mathrm{g}$ na pósmenopausa. Assim, em mulheres na pré-menopausa, devido a alta concentração dos hormônios endógenos, as lignanas exercem efeito anti-estrogênico, pois têm que competir com os esteróides endógenos pelos receptores e possuem uma afinidade muito menor. Contraditoriamente, as mesmas podem exercer ação estrogênica fraca em mulheres na pós-menopausa e em homens, devido à baixa concentração de hormônios esteróides nestes grupos, o que faz com que haja uma menor competição pelos receptores (HUTCHINS e SLAVIN, 2003).

\subsubsection{Biodisponibilidade das lignanas}

\section{a) Efeitos do processamento:}

A semente de linhaça possui uma dura casca, o que faz com que seus componentes, incluindo as liganas, não estejam biodisponíveis, a menos que a 
semente seja moída ou triturada. No entanto, nenhum estudo foi realizado para verificar as diferenças entre ingestão da semente inteira ou moída.

Com o intuito de avaliar o efeito do tratamento térmico sobre o conteúdo de lignanas excretadas pela urina, foi realizado um estudo com mulheres na prémenopausa que consumiram $25 \mathrm{~g}$ de linhaça crua ou na forma de pães e bolos e pôde-se observar que o processamento não alterou sua biodisponibilidade (NESBITT et al., 1999), sugerindo que as lignanas são estáveis às condições de cozimento. Outros estudos mostram uma redução de até $25 \%$ no conteúdo de SDG após cozimento (MUIR e WESTCOTT, 2000)

\section{b) Variabilidade entre indivíduos:}

Muitos estudos mostram uma grande variação interindividual nos níveis plasmáticos e urinários de lignanas. Além disto, apesar do enterodiol (ED) e enterolactona (EL) serem os principais produtos obtidos a partir do SDG, o balanço ED/EL costuma variar bastante entre indivíduos, sugerindo que a oxidação do ED em EL seja bastante variável, até mesmo entre pessoas do mesmo sexo. Como o metabolismo de lignanas é dependente da microbiota intestinal, a diferença pode estar relacionada às variações entre indivíduos nesta microflora e na sua habilidade em metabolizar as lignanas. Estas variações podem ser influenciadas por fatores ambientais e fisiológicos, que incluem o uso de antibióticos, gênero, dieta e fatores genéticos (NESBITT et al., 1999). A participação das bactérias intestinais foi demonstrada pela redução nas lignanas plasmáticas e na urina após o uso de antibióticos (KILKKINEN et al,, 2002). 


\section{c) Dieta:}

O metabolismo das lignanas vegetais também pode variar de acordo com a dieta habitual e passada do indivíduo. Um grande estudo transversal mostrou que maiores níveis de EL estão positivamente relacionados a ingestão diária de vegetais, fibra dietética, álcool (0,5 a 1 dose/dia), cafeína (café e chá), amêndoas, leguminosas, além de outras sementes, como gergelim (LAMPE, 1999).

Dietas ricas em vegetais e grãos integrais afetam diretamente a absorção, reabsorção e excreção de fitoestrógenos. Fibras solúveis favorecem a atividade das

enzimas $\beta$-glucuronidase e $\beta$-glicosidase pela microbiota intestinal, melhorando o metabolismo dos fitoestrógenos e aumentando a absorção destes compostos, já as fibras insolúveis diminuem a absorção das lignanas, favorecendo sua excreção. Desta forma, diferenças entre dietas podem ser responsáveis pela variabilidade nas respostas metabólicas e biológicas às lignanas (HORNER et al., 2002).

\subsection{MENOPAUSA}

A menopausa natural ocorre em torno dos 50 anos de idade e seu diagnóstico é sempre retrospectivo, ou seja, depende de um período de ausência de menstruação de, pelo menos, doze meses. Durante o climatério, com a instabilidade hormonal, surgem manifestações biológicas, psicológicas e sociais. Os sintomas precoces compreendem ondas de calor, sudorese, calafrio, cefaléia, tontura, parestesia, palpitação, fadiga, insônia, perda de memória e depressão, podendo ser avaliados pelo Índice Menopausal de Kupperman (IMK), que permite avaliação numérica da intensidade dos sintomas. A longo prazo, podem ocorrer alterações metabólicas, 
promovendo maior predisposição a doenças cardiovasculares e osteoporose, sendo necessários cuidados para controle e prevenção (BRASIL, 1994).

Como conseqüiência da falência ovariana, ocorre a interrupção da menstruação, marcando o fim da vida reprodutiva da mulher. Esta fase vem acompanhada de uma série de alterações hormonais, como baixas concentrações de estradiol ( $<20 \mathrm{pg} / \mathrm{mL})$ e altas concentrações do hormônio folículo estimulante (FSH $>40$ UI/L). Na fase de pós-menopausa, ou seja, 12 meses após a última menstruação, os sintomas passam a se manifestar mais intensamente, sendo a onda de calor (fogacho) o principal motivo para busca de um tratamento, já que interfere diretamente na qualidade de vida destas mulheres (MOM et al., 2006).

Os fogachos consistem em sensação súbita e transitória de calor moderado ou intenso, que se espalha pelo tórax, pescoço e face, podendo ou não ser acompanhados de sudorese profusa. Durante a onda de calor, há elevação da temperatura corporal (BORTOLETTO et al., 1995; HALBE, 1998). Estes sintomas estão geralmente associados a uma vaso-dilatação e alteração na temperatura corporal, que podem ser acompanhados ou não de suor e, em alguns casos, ondas de frio. Insônia ou perda na qualidade do sono podem ocorrer naquelas acometidas por calores noturnos. A duração média das ondas é de 4 minutos e sua freqüência pode variar de poucas ondas por semana até duas por hora (STEARNS et al., 2002).

Aproximadamente $2 / 3$ das mulheres na pós-menopausa apresentam ondas de calor, sendo que destas, de 10 a $20 \%$ as sentem de forma intensa. Em mulheres saudáveis, a prevalência é de 24 a $93 \%$ e esta variação pode ser explicada pelas diferentes populações de estudo, bem como pelas variações nos métodos de pesquisa e nas definições (MOM et al., 2006). Em países ocidentais, cerca de $80 \%$ das 
mulheres na menopausa apresentam ondas de calor e, destas, $30 \%$ as sentem de forma freqüente e intensa, o que representa um grande impacto na qualidade de vida (ÉDEN, 1998).

Os mecanismos de ação que conduzem às ondas de calor ainda não são suficientemente compreendidos. Sabe-se que a queda abrupta na produção de estrogênio, com a conseqüente alteração de neurotransmissores, como a serotonina e noradrenalina, pode estar relacionada a alterações no mecanismo de termoregulação. No entanto, algumas mulheres começam a sentir as ondas um a dois anos antes da menopausa e cerca de $20 \%$ continuam sentindo até 15 anos depois. Esses sintomas desaparecem no decorrer dos anos, mesmo com a manutenção do baixo nível de estrogênio (STEARNS et al., 2002).

Desta forma, permanece a dúvida sobre o principal agente desencadeador das ondas de calor. Sabe-se, entretanto, que uma pequena elevação na temperatura corporal precede às ondas, o que leva ao mecanismo de perda de calor, incluindo vaso-dilatação e suor (MOM et al., 2006).

Além disso, as ondas de calor também podem ser provocadas ou precipitadas por alguma doença sistêmica, desordem neuronal, pelo uso de álcool e drogas, por hábitos alimentares e ingestão de alguns aditivos alimentares. Outros fatores de risco incluem mulheres abaixo do peso, com pouca ou nenhuma atividade física, e fumantes (STEARNS et al., 2002; MOM et al., 2006). O Quadro 1, a seguir, mostra os principais fatores de risco associados às ondas de calor. Com relação aos dados demográficos, um estudo realizado nos EUA mostrou que mulheres afrodescendentes são mais freqüentemente acometidas pelas ondas de calor do que as caucasianas $(45,6 \%$ e $31,2 \%$ respectivamente). Menopausa cirúrgica também está 
associada a maior chance para manifestação de ondas de calor no primeiro ano $(90 \%)$.

Quadro 1 - Principais fatores de risco para ondas de calor

\section{Baixa concentração de estrogênio circulante}

Baixo IMC

Pouca ou nenhuma atividade física

Cigarro

Afro-descendentes

Baixo nível sócio- econômico

Baixo nível de instrução

Menopausa precoce

Menopausa abrupta:

-Cirúrgica

-Induzida por quimioterapia

Induzida por radiação

Induzida por drogas

Fonte: STEARNS et al., 2002.

Em pacientes saudáveis, a terapia com estrógenos, combinada ou não com progestógenos, tem se mostrado bastante eficaz na redução das ondas de calor. No entanto, após a interrupção do tratamento hormonal, a maioria das mulheres volta a apresentar os mesmos sintomas, sendo, por isso, recomendada sua interrupção gradual. Nos últimos anos, no entanto, esta terapia vem sendo contestada em decorrência da divulgação do estudo Women's Health Initiative (WHI) (ANDERSON et al., 2004; ROSSOUW et al., 2004). E a razão para isto deve-se a um pequeno, mas significante, aumento nos riscos de doenças cardiovasculares e câncer de mama em mulheres na pós-menopausa que se submeteram à terapia hormonal (STEARNS et al., 2002; MOM et al., 2006). Desta forma, a recomendação 
para terapia com hormônios vem sofrendo mudanças significativas. De acordo com a Sociedade Norte Americana de Menopausa (NAMS) esta terapia só deve ser indicada por curto período e para mulheres em que os sintomas realmente comprometam a qualidade de vida. Nos casos de simples uso para prevenção de doenças, a recomendação é não utilizar ou suspender a sua aplicação (NAMS, 2004).

Os principais tratamentos para ondas de calor, bem como seus efeitos adversos e eficácia, estão demonstrados no Quadro 2. Como pode-se observar, a grande maioria dos estudos de referência com terapias alternativas para ondas de calor, vem sendo realizada em pacientes com risco para câncer de mama, que não podem fazer uso da reposição hormonal e que normalmente apresentam uma maior prevalência para ondas de calor do que as saudáveis (MOM et al., 2006).

Quadro 2 - Diferentes tratamentos para ondas de calor.

\begin{tabular}{lllll}
\hline Tratamento & População & \multicolumn{2}{l}{ Redução das ondas Efeitos adversos } \\
\cline { 2 - 4 } & & agente & placebo & \\
\hline estrógenos & PM & $50-100 \%$ &.. & $\begin{array}{l}\text { eventos tromboembólicos, hiperplasia endometrial, retenção } \\
\text { de liquidos, desconforto na mama, sangramentos irregulares }\end{array}$ \\
progestógenos & $\mathrm{CM}, \mathrm{CP}$ & $71-90 \%$ & $21-26 \%$ & eventos tromboembólicos, ganho de peso, nausea, sangramento \\
soja & $\mathrm{CM}, \mathrm{CP}$ & $35-45 \%$ & $25-38 \%$ & constipação, flatulência, alergia, náusea, vômito \\
black colosh & $\mathrm{PM}, \mathrm{CM}$ & $27-28 \%$ & $30-32 \%$ & distúrbios gastrointestinais, náusea, hipotensão, vômitos \\
vitamina E & $\mathrm{CM}, \mathrm{CP}$ & $25 \%$ & $22 \%$ & diarréia, cansaço, fraqueza, vômito, aumento da mama \\
clonidina & $\mathrm{CM}$, tamoxifeno $37-41 \%$ & $20-27 \%$ & constipação, hipotensão, boca seca \\
SSRls & $\mathrm{PM}, \mathrm{CM}$ & $34-65 \%$ & $27-38 \%$ & boca seca, náusea, diminuição do apetite, constipação, insônia \\
\hline
\end{tabular}

*PM: pós-menopausa; CM: câncer de mama; CP: câncer de próstata Fonte: STEARNS et al., 2002.

Alguns estudos populacionais mostram que o risco de câncer hormôniodependente é maior naquelas com estilo de vida ocidental do que na população oriental, que possui uma dieta rica em fibras e fitoestrógenos (KRIS-ETHERTON et al., 2003). Segundo ADLERCREUTZ et al. (1993), estes estudos demonstram que os 
orientais e vegetarianos que possuem menor incidência de câncer de mama e endométrio, excretam concentrações relativamente mais altas de fitoestrogênios. Além disto, dados epidemiológicos mostram que menos de $25 \%$ das mulheres japonesas no climatério sofrem com ondas de calor, contra $85 \%$ das norteamericanas (ALBERTAZZI e PANSINI, 1998).

Apesar dos efeitos de uma dieta rica em lignanas ainda não terem sido muito explorados, a terapia de reposição hormonal vem mostrando bons resultados para aliviar sintomas vasomotores. Dados epidemiológicos reforçam a idéia da ação estrogênica de alguns alimentos, visto que mulheres de diferentes culturas apresentam diferentes intensidades de sintomas menopausais, e mostram que mulheres orientais, que possuem uma dieta rica em fitoestrógenos, não apresentam estes sintomas de forma tão frequente e intensa quanto as ocidentais.

Desta forma, o estudo dos efeitos de fitoestrógenos, como as lignanas, nos sintomas climatéricos, vai ao encontro de uma crescente demanda de mulheres que cada vez mais procuram formas alternativas para esta fase da vida.

\subsection{LINHAÇA E MENOPAUSA - estudos clínicos}

WILCOX et al. (1990) verificaram um aumento na maturação de células vaginais em 25 mulheres na pós-menopausa que consumiram $25 \mathrm{~g} /$ dia de linhaça in natura, mas nenhum efeito foi verificado nas concentrações dos hormônios luteinizante $(\mathrm{LH})$ e folículo estimulante $(\mathrm{FSH})$. Este estudo sugere que as lignanas mamíferas podem exercer um efeito estrogênico somente em alguns tecidos específicos, mas nenhum efeito nos hormônios derivados do sistema nervoso central. 
BRZEZINSKI et al. (1996) realizaram um estudo de 12 semanas com mulheres na pós-menopausa para verificar se uma dieta rica em fitoestrógenos (tofu, leite de soja, missô e linhaça) poderia reduzir ou aliviar os sintomas climatéricos quando comparada a uma dieta controle. Um total de 165 mulheres foram randomizadas entre as dietas e nos dois grupos houve uma redução significativa nas ondas de calor e concentração sérica de estradiol, sugerindo um efeito placebo sobre as ondas de calor. Para o grupo de estudo houve melhora significativa na secura vaginal e redução na concentração sérica de SHBG $(\mathrm{P}<0,005)$.

Segundo HUTCHINS et al. (2001), a ingestão de 5 ou $10 \mathrm{~g} /$ dia de linhaça pode influenciar as concentrações séricas dos hormônios sexuais. Um grupo de 28 mulheres consumiu 0,5 e $10 \mathrm{~g}$ de linhaça/dia, durante 7 semanas, em suplementação a sua dieta habitual. Verificou-se que durante o consumo de 5 e $10 \mathrm{~g}$ de linhaça/dia as concentrações de estradiol (E2) diminuíram em 2,9 pg/mL e 3,62 pg/mL, respectivamente. Estas reduções mostraram correlação com um aumento na excreção de enterodiol $(\mathrm{P}<0,05)$ e enterolactonas $(\mathrm{P}<0,005)$. HAGGANS et al. (1999) verificaram, no mesmo grupo, que a excreção urinária do 2 - $\alpha$-hidroxiestrona foi significativamente maior quando consumiram $10 \mathrm{~g}$ de linhaça $(14,4 \mu \mathrm{g} / 24 \mathrm{~h})$ do que quando consumiram $5 \mathrm{~g} / \mathrm{dia}(12,1 \mu \mathrm{g} / 24 \mathrm{~h}, \mathrm{p}<0,05)$ e dieta controle $(10,7 \mu \mathrm{g} / 24 \mathrm{~h}$, $\mathrm{p}<0,0005)$. Estes estudos sugerem que a suplementação da dieta com $10 \mathrm{~g}$ de linhaça é suficiente para interferir no metabolismo do estradiol.

Estudos com animais e em mulheres na pré-menopausa mostram que após o primeiro dia de consumo de $25 \mathrm{~g}$ de linhaça, o pico máximo de lignanas no plasma ocorre 9 horas após consumo e esse valor não sofre alterações significativas após 12 
ou 24 horas, sugerindo que, no caso das lignanas, apenas uma dose/dia é suficiente para manter seus níveis estáveis no plasma (NESBITT et al., 1999; WARD, 2003).

As lignanas possuem atividade antioxidante e alguns estudos demonstram que podem ser consideradas como quimioprotetoras, pois estimulam a produção de SHBG e inibem a atividade de algumas enzimas associadas à síntese de estrogênio, como a aromatase (NESBITT et al., 1999; HAGGANS et al., 2000). Além disto, o consumo da linhaça demonstrou ser capaz de reduzir o colesterol total e o LDL colesterol (BIERENBAUM et al., 1993; CUNNANE et al., 1995) bem como a agregação plaquetária (ALLMAN et al., 1995).

Alguns estudos comparativos da ingestão de soja e da semente de linhaça foram realizados, e demonstraram maior eficiência da linhaça em reduzir o LDL colesterol e triglicerídeos do plasma (RIDGES et al., 2001), além da capacidade de reduzir as concentrações séricas de ácido úrico em ensaios biológicos(VELASQUES e BHATHENA, 2001, BHATENA et al, 2002).

Muitas doenças estrogênio relacionadas, como alguns tipos de câncer, doenças cardiovasculares, osteoporose, depressão, entre outras, são aquelas que, normalmente, acometem as mulheres durante a fase do climatério. Com o processo de envelhecimento ocorrem alterações significativas na produção e no equilíbrio das concentrações séricas de diversos esteróides sexuais que exercem papel modulador sobre diversas funções, entre elas, as psíquicas (SCALCO, 2002; SOARES, 2002).

Isto acontece porque existem receptores de estrogênio em todo corpo; hoje se sabe que há dois tipos de receptores para o estrogênio: o alfa, presente nas mamas, vagina e endométrio e o beta, localizado no intestino, pulmão, ossos e bexiga, entre outros (NETO e LIMA, 2001; POVOA, 2002) 
A administração de esteróides sexuais pode, muitas vezes, apresentar efeitos colaterais ou contra-indicações clínicas que não justificam seu uso (ANDERSON et al., 2004), pois o estrogênio pode estimular órgãos proliferativos da mulher, como endométrio e mamas (receptores $\alpha$ ), gerando maior risco de câncer nesses sítios.

Os fitoestrogênios, por sua vez, possuem maior afinidade pelos receptores beta. Sua interação com o receptor, no entanto, é complexa e sofre várias influências, podendo ter ação estrogênica e anti-estrogênica, dependendo da concentração do estradiol endógeno e do órgão específico envolvido (NETO e LIMA, 2001; HUTCHINS e SLAVIN, 2003).

No entanto, estudos biológicos e in vitro com derivados de soja mostraram efeitos conhecidos de estimulação estrogênica em células endometriais (HALE et al., 2002), sugerindo uma possível ação agonista destes fitoestrogênios nestas células. Apesar de estudos com animais sugerirem um efeito proliferativo deste composto no endométrio, poucos verificaram seus efeitos em mulheres menopausadas (UPMALIS et al., 2002; BALK et al., 2002; PENOTTI et al., 2003), além de não verificarem efeito proliferativo na espessura endometrial.

Com relação ao perfil lipídico, um estudo realizado com mulheres na pósmenopausa, hipercolesterolêmicas, comparou os efeitos da ingestão de esteróides sexuais e de uma dieta à base de linhaça moída (40 g/dia). Os resultados mostraram que a linhaça foi tão efetiva quanto os hormônios na melhora dos sintomas da menopausa e na redução das concentrações séricas de glicose e de insulina, mas somente a terapia de reposição hormonal melhorou significativamente o perfil lipídico destas pacientes (LEMAY et al., 2002). 


\section{JUSTIFICATIVA}

Com o aumento da expectativa de vida média da mulher para 80 anos, atualmente, há um número crescente de mulheres que chegam a viver quase $1 / 3$ de suas vidas na pós-menopausa, com risco aumentado para sintomas vasomotores, osteoporose e doenças cardiovasculares.

Estudos sobre o tema, com objetivo de investigar os efeitos da suplementação da dieta com um alimento rico em lignanas nos sintomas climatéricos de mulheres na pós-menopausa ainda são praticamente inexistentes no nosso meio, principalmente, estudos clínicos randomizados e controlados. Desta forma, baseado nos tópicos abaixo enumerados, justifica-se o presente estudo:

1. Estudos epidemiológicos sugerem que o consumo de alimentos ricos em fitoestrógenos pode estar relacionado a menor incidência de doenças crônicas hormônio-dependentes e de sintomas vasomotores em mulheres na pós-menopausa.

2. Muitas mulheres apresentam contra-indicações para terapêutica hormonal e, dentre as que não apresentam, muitas procuram terapias alternativas devido ao receio de efeitos colaterais com o uso de hormônios esteróides;

3. Entre as terapias alternativas, o consumo de fitoestrógenos vem sendo estudado, mas em número ainda reduzido de publicações. As isoflavonas são as mais estudadas, com resultados ainda não conclusivos, sugerindo a necessidade de novos estudos clínicos. 


\section{OBJETIVOS}

\subsection{Geral:}

Avaliar os efeitos do consumo de um pão enriquecido com farinha de linhaça, rico em lignanas, sobre os sintomas climatéricos e espessura endometrial de mulheres na pós-menopausa.

\subsection{Específicos:}

Determinar a composição centesimal, o perfil de ácidos graxos e de lignanas da semente de linhaça nacional;

Desenvolver um pão de fôrma rico em lignanas e outro similar (controle) que tenham composição centesimal e aparência similares;

Verificar a estabilidade dos ácidos graxos e lignanas ao processamento e ao "armazenamento e indicar as alternativas para o aproveitamento da semente de linhaça; 


\section{BIBLIOGRAFIA}

1. ADLERCREUTZ, H.; MOUSAVI, Y.; ClARK, J.; HASE, T. Dietary phytoestrogens and cancer: in vitro e in vivo studies. J. Steroid. Biochem., v. 44, p.147-153, 1992.

2. ADLERCREUTZ, H.; et al. Quantitative determination of lignans and isoflavones in plasma of ominovirous and vegetarianas women by isotope dilution chrotographymass spectrometry. Scand. J. Clin. Lab. Invest., v. 53, p. 5-18, 1993.

3. ALBERTAZZI, P.; PANSINI, F. The effect of dietary soy supplementation on hot flushes. Obstetrics \& Gynecology, v. 91, n. 1. Jan, 1998.

4. AllMAN, M. A.; PENA, M. M.; PANG, D. Supplementation with Flaxseed oil versus Sunflowerseed oil in Helthy men consuming a low fat diet: Effects on platelet composition and function. Eur. J. Clin. Nutr., v. 49, p. 169-178. 1995.

5. ANDERSON, G. L.; LIMACHER, M.; ASSAF, A. R. et al. Effects of conjugated equine estrogen in postmenopausal women with hysterectomy - The women's health initiative randomized controlled trial. JAMA, v. 291, p. 1701-1712, 2004.

6. ARABBI, P.R., Alimentos funcionais: aspectos gerais. Nutrire: Rev. Soc. Bras. Alim. Nutr., v.21, p.87-102, jun., 2001.

7. AXELSON, M. J. et al. Origin of lignans in mammals and identification of a precursor from plants. Nature, v. 298, p. 659-660, 1982.

8. BALK, J. L.; et al. A pilot study of the effects of phytoestrogen supplementation on postmenopausal endometrium. J. Soc. Gynecol. Invesg., v. 9, p. 238-42, 2002.

9. BHATHENA, S. J.; ALI, A. A.; MOHAMED, ${ }^{a}$ I.; VELÁSQUEZ, H. Differencial effects of dietary flaxseed protein and soy protein on plasma triglyceride and uric acid levels in animal models. The Journal of Nutritional Biochemistry, v. 13, n. 11, p. 684-689, 2002.

10. BIANCO, N., Uma Nova Função para os Alimentos. Alimentos \& Tecnologia, São Paulo, SP. v. 14, n. 87, p. 26-33, 2000.

11. BIERENBAUM, M. L., REICHESTEIN, R., WATKINS, T. R. Reducing Atherogenic Risk in Hyperlipemic Humans with Flaxseed Supplementation: A preliminary Report. J. Am. Coll. Nutr., v. 12, p. 501-504. 1993.

12. BOMBO, A. J. Obtenção e caracterização nutricional de snacks de milho (Zea mays L) e linhaça (Linum usitatissimum L). 2006. 96p. Dissertação (Mestrado em Saúde Pública) - Faculdade de Saúde Pública, Universidade de São Paulo, São Paulo. 
13. BORTOLETTO, C. d. C. R., et al. Sintomas vasomotores: Aspectos Fisiopatológicos, Clínicos e Terapêuticos. Femina, v. 23, n. 2, p. 131-135, 1995.

14. BRASIL, Ministério da Saúde. Departamento de Assistência e Promoção à Saúde/Coordenação Materno-Infatil. Assistência ao Climatério, Brasília (DF), 1994

15. BRASIL ${ }^{\mathrm{a}}$, Ministério da Saúde. Agência Nacional de Vigilância Sanitária. Resolução $\mathrm{n}^{\circ} 18$ de 30 de abril de 1999. Aprova o regulamento técnico que estabelece as diretrizes básicas para análise e comprovação de propriedades funcionais e ou de saúde alegadas em rotulagem de alimentos. Diário Oficial da União, de 03 de maio de 1999.

16. BRASIL ${ }^{\mathrm{b}}$, Ministério da Saúde. Agência Nacional de Vigilância Sanitária. Resolução $\mathrm{n}^{\circ} 19$ de 30 de abril de 1999. Aprova o regulamento técnico de procedimentos para registro de alimentos com alegação de propriedades funcionais e ou de saúde em sua rotulagem. Diário Oficial da União, de 03 de maio de 1999.

17. BRZEZINSKI, A. et al. Phytoestrogen-rich diet: A possible alternative for hormone replacement therapy. Menopause, v. 3, n. 4, p. $251,1996$.

18. CARDOSO-SAntiagO, R. A.; AREAS, J. A. G. Nutritional evaluation of snacks obtained from chickpea and bovine lung bleds. Food Chem., v. 74, p. 35-40, 2001

19. CháveZ-Jareugui, R. N. PINTO E Silva, M. E. M.; ARÊAS, J. A. G. Extrusion cooking process of amaranth (Amaranthus caudatus L.). J. Food Sci., v. 65 , n. 6, p. 1009-1015, 2000.

20. CUNnANE, S. C., HAMADEH, M. J., LiEDE, A. C., THOMPSON, L. U., WOLEVER, T. M. S., JENKINS, D. J. A. Nutritional Attributes of Traditional Flaxseed in Healthy Young Adults. Am. J. Clin. Nutr., v. 61, p. 62-8, 1995.

21. DAUN, J. K. et al. Structture, composition and variety development of flaxseed. In: Flaxseed in human nutrition, Champaign, Illinois: AOCS Press, 2003, p. 1-40.

22. DEMARK-WAHNEFRIED, W.; PRICE, D. T.; POLASCIK, T. J.; ROBERTSON, C. N., ANDERSON, E. E., PAULSON, D. F., WALTHER, P. J., GANNON, M., Pilot Study of Dietary restriction and Flaxseed Supplementation in Men with Prostate Cancer Before Surgery: exploring the effects on hormonal levels, prostate-specific antigen, and histopathologic features. Urology, p. 17-52. Jul., 2001.

23. EDEN, J. Phytoestrogens and menopause. Clinical endocrinology and metabolism v.12, p.581-587, 1998.

24. GROWER, D., Flaxseed. Bi-weekly Bulletin, v. 15, p.1-4, 2002.

25. HAGGANS, C. J. et al. Effect of flaxseed consumption on urinary estrogen metabolites in postmenopausal women. Nutr. Cancer., v. 33, p. 58-65, 1999. 
26. HAGGANS, C. J.; TRAVELLI, E. J.; THOMAS, W.; The effect of flaxseed and wheat bran consumption on urinary estrogen metabolites in premenopausal women. Cancer Epidemiology Biomarkers and Prevention, v. 9, p. 719-725, 2000.

27. HALBE, H.W. Tratado de Ginecologia. 2. ed. São Paulo: Rocca. p. 1236-1258, 1998. v. 2.

28. HALE, G. E.; HUGHES, C. L.; CLINE, J. M. Endometrial cancer: hormonal factors, the perimenopausal "window of risk", and isoflavones. J. Clin. Endocrinol. Metabolism, v. 87, p. 3-15, 2002.

29. HASLER, C. M. Functional Foods: their role in disease prevention and health promotion. Food Technology, V. 52, n. 11, nov., 1998.

30. HORNER, N. K. et al. Dietary determinants of plasma enterolactone. Cancer Epidemiology Biomarkers \& Prevention, v. 11, p. 121-126, 2002.

31. HUTCHINS, A. M.; MARTINI, M. C.; OLSON, B. A.; THOMAS, W.; SLAVIN, J. L. Flaxseed influences urinary lignan excretition in a dose -dependent manner in post-menopausal women. Cancer Epidemiology Biomarkers \& Prevention, v. 9, p. 1113-1118, Oct., 2000.

32. HUTCHINS, A. M. et al. Flaxseed consumption influences endogenous hormone concentrations in postmenopausal women. Nutr. Cancer, v. 39, p. 58-65, 2001.

33. HUTCHINS, A. M; SLAVIN, J. L. Effects of flaxseed on sex hormone metabolism. In: Flaxseed in human nutrition, Champaign, Illinois: AOCS Press, 2003, p. 92-116.

34. KILKKINEN, A et al. Use of oral antimicrobials decreases serum enterolactone concentration. Am. Epidemiol., v. 155, p. 472-477, 2002.

35. KRIS-ETHERTON, P., HECKER, K. D., BONANOME, A., COVAL, S. M., BINKOSKI, A. E., HILPERT, K. F., GRIEL, A.E., ETHERTON, T. D. Bioactive Compounds in Foods: their role in prevention of cardiovascular disease and cancer. The American Journal of Medicine, Jan., 2003.

36. LAMPE, J. W. Urinary isoflavonoid and lignan excretion on a western diet: relation to soy, vegetable and fruit intake. Cancer Epidemiol. Biomark. Prev., v. 8, p. $699-707,1999$.

37. LEMAY, A; DODIN, S.; KADRI, N.; JACQUES, H.; FOREST, J. C. Flaxseed dietary supplement versus hormone replacement therapy in hypercholesterolemic menopausal women. Obstetrics \& Gynecology, Aug, 2002.

38. MENDONÇA, S. Efeito hipocolesterolemizante da proteína de amaranto (Amaranthus cruentus, BRS-Alegria) em hamsters. 2006, 206p. Tese (Doutorado em Saúde Pública) - Faculdade de Saúde Pública, Universidade de São Paulo, São Paulo. 
39. MOM, C.H.; BUIJS, C.; WILlEMSE, P. H. B.; MOURITS, M. J. E.; DE VRIES, E. G. E. Hot flushes in breast cancer patients. Critical reviews in oncology/hematology, v. 57, p. 63-77, 2006.

40. MOREIRA-ARAÚJO, R. S. R.; ARAUJO, M. A. M.; SILVA, A. M. S.; CARVALHO, C. M. R.; ARÊAS, J. A. G. Impacto de salgadinho de alto valor nutritivo na situação nutricional de crianças de creches municipais de Teresina-PI. Nutrire, v. 23, p. 7-21, 2002.

41. MUIR, A. D.; WESTCOTT, N. D. Quantification of the lignan secoisolariciresinol diglucoside in baked goods containing flaxseed or flax meal. J. Agric. Food Chem., v. 48, p. 4048-4052, 2000.

42. NAMS - North American Menopause Society, Treatment of menopauseassociated vasomotor symptoms: position statement of The North American Menopause Society, Menopause, v. 11, p. 11-33, 2004.

43. NESBITT, P. D.; LAM, Y.; THOMPSON, L. U. Human metabolism of mammalian lignan precursors in raw and processed flaxssed. Amer. J. Clin. Nutrition, v. 69, n. 3, p. 549-555, Mar., 1999.

44. NETO, J. S. P.; LIMA, J. C. Terapia de reposição hormonal e sistema nervoso central. Femina, v. 29, n. 7, p. 451-456, 2001.

45. O LINHO. Revista Globo Rural, n. 171, p. 1, (2000).

46. OOMAH, B. D.; MAZZA, G.; KENASCHUK, E. O. Cyanogenic compounds in flaxseed. J. of Agric. Food Chem., v. 40, p.1346-1348, 1992.

47. PENOTTI, M.; FABIO, E.; MODENA, A. B.; RINALDI, M.; OMODEI, U.; VIGANO, P. Effect of soy-derived isoflavones on hot flushes, endometrial thickness, and the pulsatility index of the uterine and cerebral arteries. Fertil. Steril., v.79, p. 1112-1117, 2003.

48. PRASAD ${ }^{\mathrm{a}}, \mathrm{K}$. Flaxseed and prevention of experimental hypercolesterolemic atherosclerosis. In: Flaxseed in human nutrition. Champaign, Illinois: AOCS Press, 2003, p. $260-273$.

49. PRASAD ${ }^{b}, K$. Flaxseed components in the prevention of experimental diabetes. In: Flaxseed in human nutrition. Champaign, Illinois: AOCS Press, 2003, p. 274287.

50. PÓVOA, H. O cérebro desconhecido: como o sistema digestivo afeta nossas emoções, regula nossa imunidade e funciona como um órgão inteligente. Rio de Janeiro: Objetiva, 2002.

51. ROSSOUW, J. E.; ANDERSON, G. L.; et al. Risks and benefits of estrogen plus progestin in healthy postmenopausal women - Principal results from the Women's Healthy Initiative randomized Controlled Trial. JAMA, v. 291, p.1701-1712, 2004. 
52. RICKARD, S. E.; THOMPSON, L. U. Health effects of flaxseed mucilage, lignans. Inform., v.8, p. 860-865, 1997.

53. RIDGES L.; SUNDERLAND, R.; MOERMAN, K.; HOWE, P. Cholesterol lowering benefits of soy and linseed enriched foods. Asia Pac. J. Clin. Nutr., v. 10, n. 3, p. 204-211, 2001.

54. SCALCO, M. Z. Depressão e Menopausa. Femina, v. 30, n.1, p. 51-55, 2002.

55. SOARES, C. N.; PROUTY, J.; POITRAS, J. Ocorrência e tratamento de quadros depressivos por hormônios sexuais. Rev. Bras. Psiquiatr., v. 24, n. 1, p 48-54, 2002.

56. SETCHEL, K. D. R. et al. Lignans in man and in animal species. Nature, v. 287, p. $740-742,1980$.

57. SETCHEL, K. D. R. et al. Lignan formation in man - Microbial involvement and possible roles in relation to cancer. Lancet, v. 2, p. 4-7, 1981.

58. STEARNS, V.; ULLMER, L.; LOPEZ, J.F.; et al. Hot flushes, Lancet, v. 360, p. 1851-1861, 2002.

59. STITCH, S. R. et al. Isolation and structure of a new phenolic constituent of female urine. Nature, v.287, p. 738-740, 1980.

60. THOMPSON, L. U.; ROBB, P.; SERRAINO, M.; CHEUNG, F. Mammalian lignan production from various foods. Nutrition and Cancer, v. 16, n. 1, p. 43-52, 1991.

61. THOMPSON ${ }^{\mathrm{a}}$, L. U. Analysis and bioavaiability of lignans. In: Flaxseed in human nutrition. 2. ed. Champaign, Illinois: AOCS Press, 2003, p. 92-116.

62. THOMPSON ${ }^{\mathrm{b}}$, L. U. Flaxseed, lignans and cancer. In: Flaxseed in human nutrition. 2. ed. Champaign, Illinois: AOCS Press, 2003, p. 194-222.

63. ThOMPSON, L. U.; CUNNANE, C. C. Flaxseed in Human Nutrition. 2. ed. Champaign, Illinois: AOCS Press, 2003.

64. UPMALIS, D. H.; LOBO, R.; BRADLEY, L.; WARREN, M. et al. Vasomotor symptom relief by soy isoflavone extract tablets in postmenopausal women: a multicenter, double-blind, randomized, placebo-controlled study. Menopause, v. 7, p. 236-242, 2002.

65. VELASQUES, M. T.; BHATHENA, S. J. Dietary phytoestrogens: a possible role in renal disease protection. American Journal Kidney Disease, v. 37, n. 5, p. 105668, 2001.

66. WARD, W. E. Effect of flaxseed on bone metabolism and menopause. In: Flaxseed in human nutrition. Champaign, Illinois: AOCS Press, 2003, p. 92-116. 
67. WILCOX, G. et al. Oestrogenic effects of plant foods in postmenopausal women. Br. Med. J., v. 301, p. 905-906, 1990.

68. WHO. Diet, Nutrition and Prevention of Chronic Diseases. Report of the Joint FAO/WHO Expert Consultation, Abril, 2002.

69. ZERO HORA, Linhaça avança e rouba espaço do trigo. Disponível em: http://www.zerohora.com.br. Acesso em 14 out. 2005. 


\section{CAPÍTULO 2}




\section{CARACTERIZAÇÃO DA SEMENTE DE LINHAÇA NACIONAL E ESTABILIDADE DOS ÁCIDOS GRAXOS AO PROCESSAMENTO}

\section{INTRODUÇÃO:}

Apesar de diversas pesquisas internacionais divulgarem os benefícios do consumo de linhaça à saúde, no Brasil, informações sobre a composição química e perfil de ácidos graxos da semente nacional ainda são escassos.

Segundo DAUN et al. (2003), a variação na sua composição pode ocorrer de acordo com o local de produção, variedade e metodologia empregada na determinação destes componentes. Mas em média a semente de linhaça possui $40 \%$ de óleo, $30 \%$ de fibras, $20 \%$ de proteínas, $4 \%$ de cinzas e $6 \%$ de umidade. O Quadro 1 mostra a variação de 11 amostras plantadas no EUA, analisadas em Dakota do Norte.

Quadro 1 - Composição média de 11 variedades de linhaça.

\begin{tabular}{|c|c|}
\hline COMPONENTES & CONTEÚDO \\
\hline Umidade & $7,1-8.3$ \\
\hline Lipídios* & $31,9-37,8$ \\
\hline Proteínas & $26,9-31,6$ \\
\hline Total de Fibras & $36,7-46,8$ \\
\hline Fibras Solúveis & $\sim 10$ \\
\hline Fibras Insolúveis & $\sim 30$ \\
\hline \multicolumn{2}{|c|}{ *COMPOSIÇÃO DE ÁCIDOS GRAXOS } \\
\hline Palmítico & $4,5-6,3$ \\
\hline Esteárico & $3,3-6,1$ \\
\hline Oléico & $19,3-29,4$ \\
\hline Linoléico & $14-18,2$ \\
\hline Linolênico & $44,6-51,5$ \\
\hline
\end{tabular}

Fonte: Berglund, 2002. 
Como pode-se observar esta é uma semente oleaginosa e seu óleo é relativamente pobre em ácidos graxos saturados (10\%), possui em torno de $20 \%$ de monoinsaturados e é altamente rico em polinsaturados, podendo chegar até $75 \%$ do seu total. Os níveis de insaturação podem variar de acordo com a espécie e temperatura de plantio, tendo sido demonstrado que aquelas sementes plantadas em locais mais frios possuem um maior teor de insaturação (DAUN et al., 2003).

Este perfil faz com que o óleo de linhaça seja um dos mais polinsaturados entre os óleos comuns e por isto é vendido em embalagens opacas e deve ser mantido sob refrigeração depois de aberto, sendo indicado para uso em preparações frias, como saladas.

A semente contém uma série de substâncias fenólicas e antioxidantes que podem exercer papel protetor na prevenção à oxidação lipídica. Mas no desenvolvimento de produtos a base de farinha de linhaça é importante estudar o comportamento destes ácidos graxos sob diferentes condições de armazenamento e processamento de modo a garantir que seus componentes ativos estejam presentes no produto final.

O uso da semente na forma de farinha como ingrediente na produção de pães e bolos seria uma ótima alternativa para agregar valor a estes produtos e eliminar fatores antinutricionais presentes na semente. Além disto, como sua mucilagem dificulta a trituração ao mastigar, a recomendação é de que se consuma a semente já na forma de farinha para que se tenha um melhor aproveitamento nutricional.

Desta forma, torna-se importante verificar a estabilidade da linhaça e da sua farinha durante o armazenamento sob diferentes temperaturas e durante processamento, de forma a evitar a oxidação e transformação destes ácidos graxos. 
Assim, este teve como objetivo caracterizar a semente de linhaça nacional e verificar as melhores condições de armazenamento para farinha de linhaça, bem como verificar o efeito da temperatura de processamento sobre a qualidade do produto final, de modo a garantir seu consumo de forma segura e eficaz.

\section{MATERIAL E MÉTODOS:}

\subsection{MATERIAL}

Foram analisados dois tipos de produtos encontrados no mercado nacional. A semente de linhaça integral e uma farinha de linhaça parcialmente desengordurada, sub-produto da extração do óleo de linhaça por prensagem a frio, ambas cultivadas na região Sul do país.

Para sua análise, a semente integral foi moída em moinho martelo (modelo MML-100) para obtenção de uma farinha integral.

Um lote de $60 \mathrm{Kg}$ da farinha de linhaça foi doado pela Indústria de óleos vegetais Pazze Ltda, Panambi - RS e estocada sob refrigeração e congelamento para posterior uso no estudo clínico. Nesta amostra também foram realizados testes para verificar as melhores condições de estocagem para este produto. 


\subsection{MÉTODOS}

\subsubsection{Composição Centesimal}

As análises físico-químicas foram realizadas em triplicata nas duas amostras. A composição centesimal foi determinada de acordo com as Normas Analíticas do Instituto Adolfo Lutz (IAL, 1985) e pela AOAC (1990):

$\Rightarrow$ umidade por dessecação em estufa a $105^{\circ} \mathrm{C}$ até peso constante;

$\Rightarrow$ proteína pelo método de Micro-Kjeldhal;

$\Rightarrow$ lipídeos por extração em Soxhlet, com uso de éter de petróleo;

$\Rightarrow$ cinzas por incineração em mufla a $550^{\circ} \mathrm{C}$ por 12 horas;

$\Rightarrow$ fibras dietéticas pelo método de PROSKY et al. (1985).

\subsubsection{Perfil de Ácidos Graxos}

O perfil de ácidos graxos foi determinado na farinha da semente integral. Outros testes foram realizados para verificar os efeitos da temperatura de processamento e armazenamento sobre o perfil de ácidos graxos da semente integral. Para isto as sementes foram torradas, inteiras e na forma de farinha, a $210^{\circ} \mathrm{C}$ por 10 minutos e, posteriormente, analisadas. Outro teste foi realizado incorporando a farinha de linhaça integral na produção de pães. Amostras foram retiradas da massa antes e após cozimento (35 min. a $\left.210^{\circ} \mathrm{C}\right)$ e outras duas após armazenamento por 7 dias, à temperatura ambiente e de refrigeração, para verificar as alterações no perfil de ácidos graxos durante cozimento e armazenagem deste produto. 
Para análise dos ácidos graxos, a extração da fração lipídica foi realizada a frio, pelo método de coluna seca (MARMER e MAXWELL, 1981). Alíquotas de, aproximadamente, $50 \mathrm{mg}$ de lipídeos foram esterificadas com ácido sulfúrico, após saponificação com uma solução de hidróxido de sódio $0,5 \mathrm{~N}$ metanólico (HARTMAN e LAGO, 1973) e foram analisadas por cromatografia gasosa em coluna capilar (Cromatógrafo Chrompack CP9002) para sua caracterização.

Foi utilizado como padrão o Lipid Standard SIGMA ${ }^{\circledR}$ - Fatty acid methyl ester mixtures \# 189-19.

As condições cromatográficas foram as seguintes:

"coluna capilar de sílica fundida "CP-SIL 88", marca Varian, com 50m de comprimento e $0,25 \mathrm{~mm}$ de diâmetro interno;

Gás de arraste: hidrogênio a 1,50 mL /min;

—injetor "splitter" a $270^{\circ} \mathrm{C}$, com razão de "split" de 1:67;

- detector de ionização de chama a $300^{\circ} \mathrm{C}$;

- programação da coluna: temperatura inicial de $100^{\circ} \mathrm{C}$, com elevação de $5^{\circ} \mathrm{C} / \mathrm{min}$ até $240^{\circ} \mathrm{C}$.

O volume injetado de cada isolado no cromatógrafo a gás foi de $2 \mu \mathrm{L}$. Os picos dos principais ésteres metílicos de ácidos graxos foram identificados através do tempo de retenção, comparado ao tempo de retenção de uma mistura de padrões, e sua quantificação foi baseada na área do pico comparada com a área de cada pico da curva padrão, construída usando concentrações conhecidas de metil ésteres. 


\subsubsection{Avaliação da Oxidação Lipídica pelo método de TBA (Ácido Tiobarbitúrico):}

$\mathrm{O}$ índice de TBA é expresso em miligramas de malonaldeído por quilo de amostra e é um dos métodos mais utilizados para se detectar a oxidação de lipídeos em sistemas biológicos, embora seja um procedimento empírico relacionado com a presença de aldeídos. O malonaldeído é obtido, em pequenas quantidades, pela oxidação de lipídios polinsaturados quando aquecidos em meio ácido. Este teste se baseia na formação de um complexo róseo formado pela reação de 2 moles de TBA com um mole do produto da oxidação lipídica (malonaldeído), que é medido fotometricamente a $532 \mathrm{~nm}$ (ARAUJO, 2004).

O método utilizado foi adaptado pelo Laboratório de Bromatologia do Departamento de Nutrição/USP (TORRES E OKANI, 1997). Para esta determinação foram utilizados $5 \mathrm{~g}$ de amostra que foi homogeneizada com $40 \mathrm{~mL}$ da solução de TCA 7,5\%. Após 5 minutos de descanso, passou por centrifugação. O sobrenadante foi colhido e filtrado e ao filtrado foi adicionada uma solução de TCA completando o volume até $50 \mathrm{~mL}$. Em um tubo de ensaio com tampa rosqueada foram adicionados 5 $\mathrm{mL}$ da solução contendo o filtrado, ao qual foram adicionados $5 \mathrm{~mL}$ da solução de TBA, e após fervura por 40 minutos, esta solução foi lida contra o branco em espectrofotômetro com comprimento de onda de $538 \mathrm{~nm}$.

Para determinação da concentração de malonaldeído na amostra é necessária a construção da curva padrão do ácido 1,1,3,3 - tetra-etoxipropano (TEP) e a determinação da taxa de recuperação nas amostras. 


\section{RESULTADOS E DISCUSSÃO}

\subsection{COMPOSIÇÃO CENTESIMAL}

Na Tabela 1 a seguir, estão apresentadas as médias de macronutrientes na semente de linhaça integral e na farinha, parcialmente desengordurada.

Tabela 1 - Composição centesimal* de amostras nacionais (base seca).

\begin{tabular}{lcc}
\hline & Integral & Desengordurada \\
\hline Proteínas & $21,6(0,30)$ & $33,4(0,59)$ \\
Lipídeos & $38,9(0,53)$ & $16,8(0,21)$ \\
Cinzas & $4,1(0,46)$ & $4,9(0,11)$ \\
Fibra Solúvel & $10,7(1,45)$ & $14,6(1,50)$ \\
Fibra Insolúvel & $25,7(1,50)$ & $35,0(1,96)$ \\
\hline
\end{tabular}

* média (desvio-padrão)

A farinha de linhaça desengordurada apresenta conteúdo de proteínas e fibras maiores, como esperado. Como as lignanas estão presentes na parte fibra da semente, a farinha desengordurada forneceria uma maior quantidade deste composto, sendo uma alternativa para maximizar o conteúdo de lignanas em produtos de panificação.

Os valores de lipídeos, proteínas e cinzas na semente integral estão de acordo com a literatura internacional (Quadro 1).

Com relação ao conteúdo de carboidratos, a semente de linhaça contém em média menos de $1 \%$ de seu conteúdo de açúcares simples, sendo sua maior parte constituída daqueles carboidratos resistentes à ação das enzimas digestivas, as fibras dietéticas, sendo considerada uma ótima fonte de fibras solúveis e insolúveis. De acordo com DAUN et al. (2003), a razão fibra solúvel:insolúvel pode variar de 2080:40-60 na semente de linhaça, de acordo com método de extração e análises químicas utilizadas. Neste caso, obtivemos uma relação de 30:70. O grande conteúdo 
de fibras na semente trouxe alguns problemas na sua análise, pela dificuldade em filtrar a alíquota de $1 \mathrm{~g}$, tendo sido necessário diminuir para 0,3 g.

\subsection{PERFIL DE ÁCIDOS GRAXOS}

Para caracterização da semente de linhaça nacional, primeiro foram analisados o perfil de ácidos graxos de 3 diferentes amostras da semente integral vendidas comercialmente. A Tabela 2 abaixo mostra a variação entre as amostras analisadas.

Tabela 2 - Perfil de ácidos graxos na semente de linhaça nacional (\%).

\begin{tabular}{cccccc}
\hline \hline & Palmítico & Esteárico & Oléico & Linoléico & aLinolênico \\
& C 16:0 & C18:0 & C18:1 & C18:2 & C18:3 \\
\hline $\mathbf{1}$ & 6,36 & 4,86 & 20,21 & 13,64 & 49,34 \\
$\mathbf{2}$ & 6,78 & 7,10 & 22,33 & 13,00 & 47,17 \\
$\mathbf{3}$ & 6,60 & 4,50 & 21,40 & 13,20 & 48,60 \\
\hline \hline
\end{tabular}

Pode-se observar que o conteúdo de ácidos graxos não variou muito entre as amostras analisadas. Também é possível verificar a alta concentração de ácidos graxos polinsaturados (linoléico e linolênico), em torno de $65 \%$. O conteúdo do ácido $\alpha$-linolênico (ALA) faz com que a semente seja a maior fonte vegetal de ômega 3. Este ácido graxo é essencial e de acordo com a FAO, a recomendação para ingestão de ômega 3 é de 1 a 2 g/dia, com uma proporção de linoléico:linolênico de 6:1. No entanto, como este ácido graxo é deficiente na dieta ocidental, esta proporção 
gira em torno de 20:1. A segunda maior fonte vegetal de ALA é o óleo de canola com, aproximadamente, $11 \%$, muito inferior a linhaça $(\sim 50 \%)$. Desta forma, a semente de linhaça é uma alternativa viável e barata para suplementação de produtos com ômega 3 (CUNNANE, 2003).

Para verificar o efeito do processamento térmico sobre o perfil de ácidos graxos da semente, comparou-se amostras in natura e torrada (inteira e na forma de farinha) à $210^{\circ} \mathrm{C}$ por 10 minutos.

Analisando os cromatogramas obtidos pôde-se observar uma maior alteração no perfil de ácidos graxos da semente torrada inteira, que apresentou um novo pico entre os ácidos graxos linoléico e $\alpha$-linolênico, que pode ser de um isômero formado durante o processamento térmico. Neste mesmo cromatograma, pôde-se observar picos de menor área relativos à ácidos graxos trans e a presença de outros ácidos graxos, de 16 e 17 carbonos, assim como o incremento na área de outros picos relativos à acidos graxos de cadeia curta, o que não foi observado nos cromatogramas das demais amostras. Desta forma, a semente moída inteira apresentou uma maior modificação em seu perfil de ácidos graxos quando comparado a semente in natura. Para afirmar se houve degradação do ácido $\alpha$ linolênico seria necessária a utilização de padrão interno, para proceder a análise quantitativa.

RATNAYAKE et al. (1992) demonstraram que tanto a semente moída quando inteira, quando submetidas ao aquecimento $\left(100\right.$ ou a $\left.350^{\circ} \mathrm{C}\right)$ por 60 minutos, não apresentaram alterações na sua composição de ácidos graxos ou nas medidas de oxidação lipídica. 
No mesmo sentido, $40 \%$ de farinha de linhaça integral foram utilizados na produção de um pão para verificar os efeitos do processamento e armazenamento sobre o perfil de ácidos graxos (Gráfico 1). Foram retiradas amostras do pão antes e após cozimento $\left(35 \mathrm{~min} . \mathrm{X} 210^{\circ} \mathrm{C}\right)$ e do mesmo armazenado por 7 dias sob temperatura ambiente e de refrigeração.

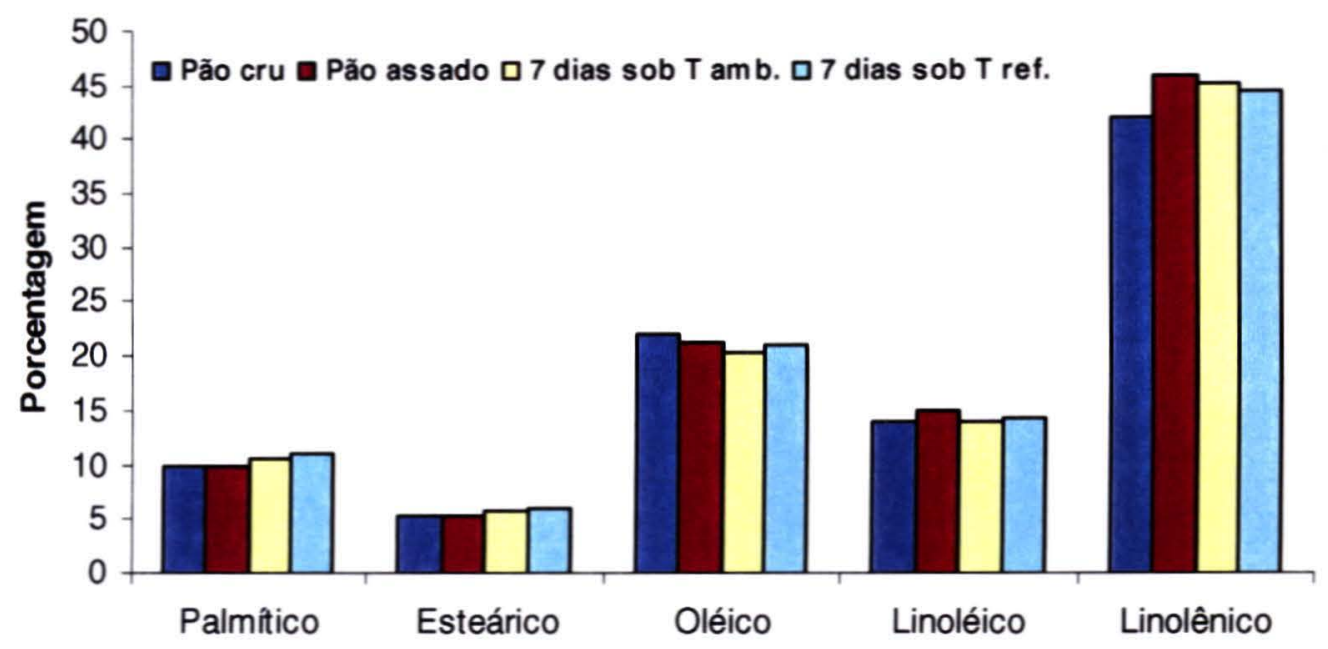

Gráfico 1 - Variação nos teores de ácidos graxos após processamento e armazenamento dos pães.

Os resultados mostram que tanto o processamento, quanto o armazenamento não interferiram de forma significativa no perfil de ácidos graxos das amostras. Alguns outros estudos (CUNNANE et al., 1994; MANTHEY et al., 2002) confirmam a estabilidade do ALA em produtos de panificação, já que o calor é transferido de forma indireta ao produto. CHEN et al. (1994) verificaram que o conteúdo de ALA não se modifica após duas horas de cozimento a $178^{\circ} \mathrm{C}$, em muffins produzidos com 28,5\% de linhaça. Existe também uma evidência biológica da estabilidade do ômega 
3 ao cozimento na forma de produtos de panificação. CUNNANE et al. (1993) comparou o perfil de ácidos graxos no plasma de mulheres que consumiram $50 \mathrm{~g}$ de linhaça in natura com outro que consumiu o equivalente na forma processada (pães), durante quatro semanas, e nenhuma diferença significativa foi encontrada.

Testou-se também a estabilidade da farinha de linhaça armazenada sob diferentes temperaturas. Após a moagem da semente, a farinha foi armazenada por 2 semanas à temperatura ambiente, de refrigeração e de congelamento. O gráfico 2 abaixo mostra a variação no perfil de ácidos graxos.

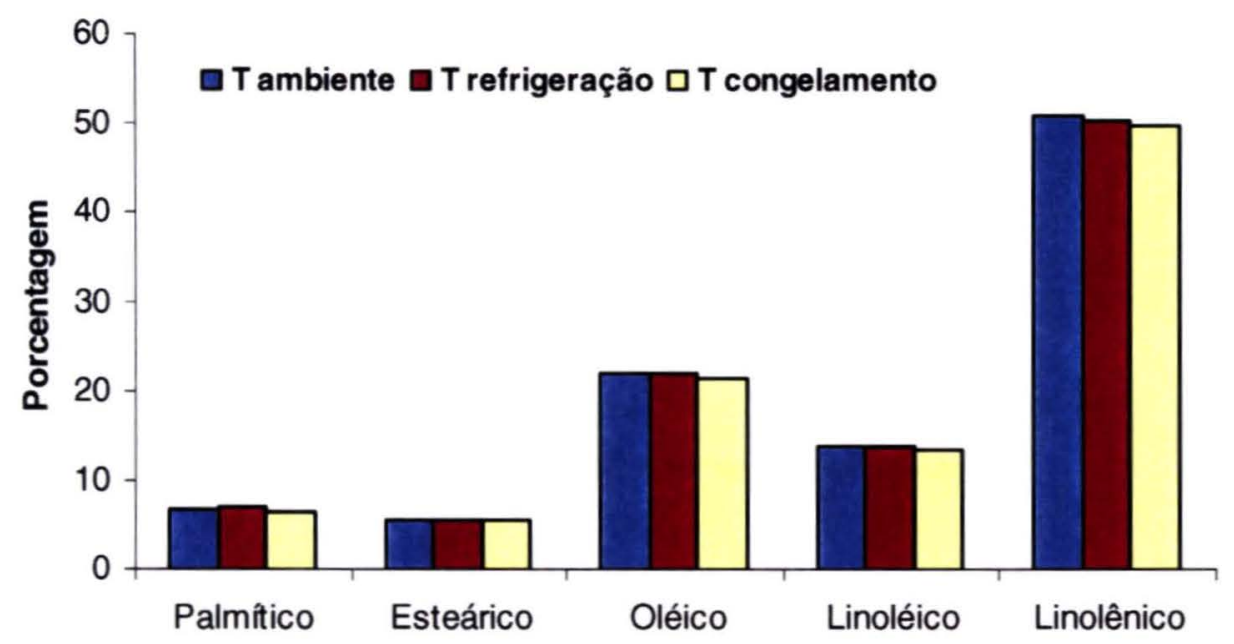

Gráfico 2 - Variação nos ácidos graxos entre amostras armazenadas sob diferentes temperaturas durante 2 semanas.

Como pode-se observar não houve variação significativa no perfil de ácidos graxos nas amostras armazenadas sob diferentes temperaturas. 


\subsection{AVALIAÇÃO DA OXIDAÇÃO LIPÍDICA}

O teste de TBA (ácido 2-tiobarbitúrico) foi realizado para determinar a oxidação lipídica da semente moída e armazenada sob diferentes temperaturas (ambiente, refrigeração e congelamento), de modo a predizer a melhor forma de armazenamento da farinha de linhaça após moagem. Para isto, as sementes moídas foram armazenadas e analisadas ao final de 2 semanas e de 70 dias.

A curva padrão do ácido 1,1,3,3 - tetra-etoxipropano (TEP) utilizada como base para o cálculo de $\mathrm{D}$ pode ser observada no gráfico 3 abaixo.

\section{Curva padrão TEP}

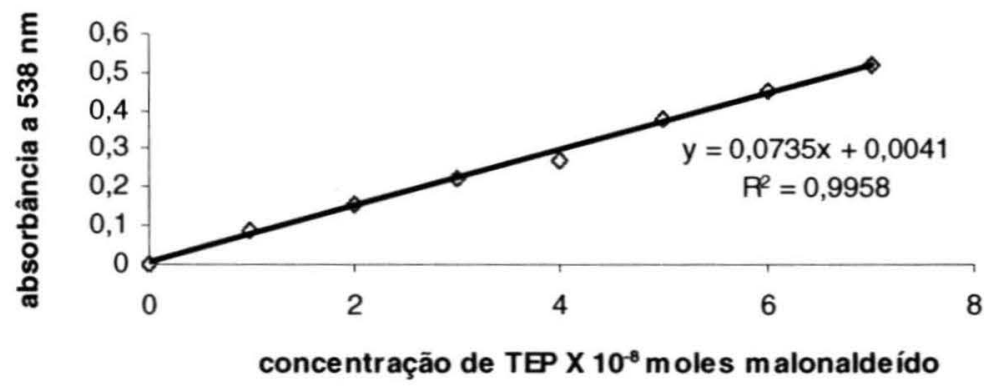

Gráfico 3 - Curva Padrão TEP.

O gráfico 4 a seguir mostra a produção de malonaldeído nas amostras armazenadas sob diferentes temperaturas após um período de 2 semanas. 


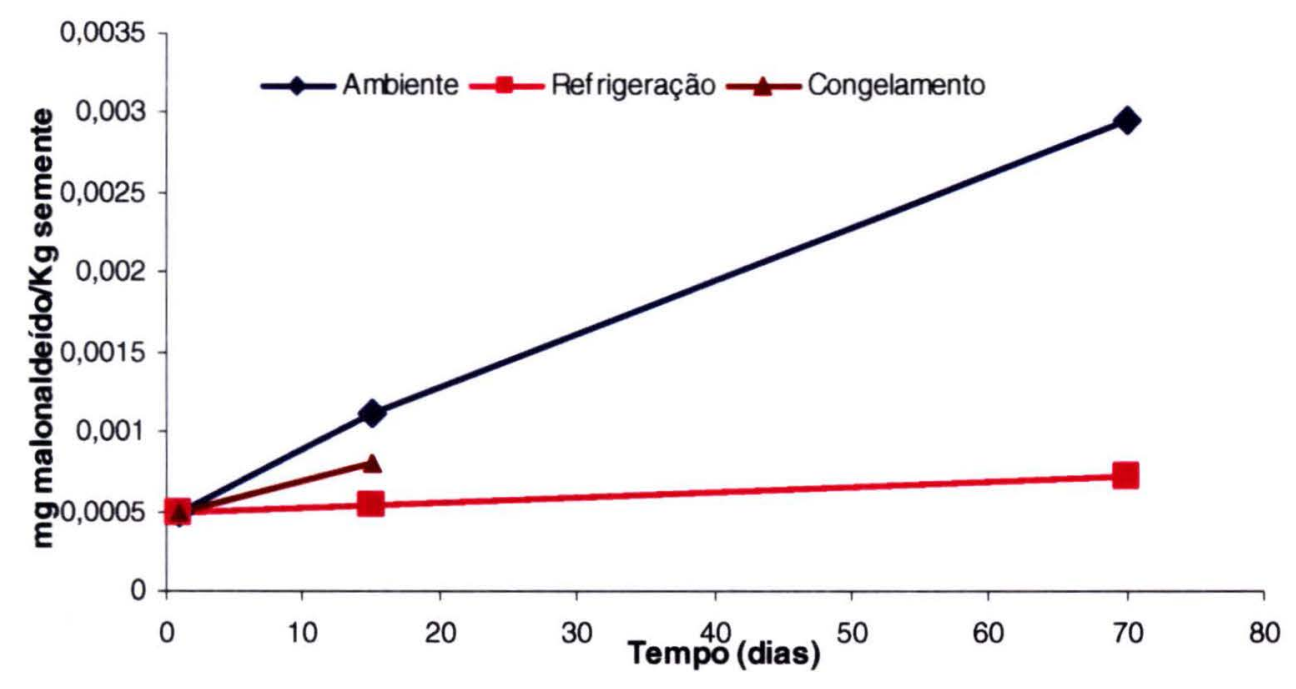

Gráfico 4 - Efeito de diferentes temperaturas de armazenamento sobre a concentração de malonaldeído.

De acordo com os resultados, pode-se observar que a temperatura de refrigeração é a mais indicada para armazenamento da farinha de linhaça. Isto pode ser explicado porque sob baixas temperaturas, como a de congelamento, a menor atividade de água (Aa) favorece a reação de oxidação lipídica. $\mathrm{O}$ congelamento diminui a quantidade de água livre no alimento, e valores de Aa abaixo de 0,4 aceleram a reação de oxidação (CHEFTEL et al., 2000). Por isto alimentos com alto teor de lipídeos insaturados e baixa Aa não devem ser congelados.

Estas medidas foram realizadas com o objetivo de verificar a oxidação lipídica na linhaça e analisar as melhores condições para seu armazenamento.

Apesar de apresentar menor estabilidade à temperatura ambiente, a concentração final de malonaldeído $(0,0029 \mathrm{mg} / \mathrm{Kg})$ na amostra armazenada por 70 dias ainda é relativamente baixa, quando comparada aos valores presentes em outros alimentos analisados por TORRES E OKANI (1997) que estavam em bom estado de 
conservação (Quadro 2). Isto pode ser confirmado pelos resultados obtidos na análise de ácidos graxos (Gráfico 3), que mostra que o perfil se mantém nas amostras armazenadas sob diferentes temperaturas.

Sob temperatura de refrigeração o teor de malonaldeído, ao final de 70 dias, passou de 0,0005 para $0,0007 \mathrm{mg} / \mathrm{Kg}$.

Quadro 2 - Concentração de malonaldeído presente em alimentos analisados no estado em que são consumidos.

\begin{tabular}{cccc}
\hline Alimento & mg malonaldeído/Kg & Alimento & mg malonaldeído/Kg \\
\hline Leite em pó & 0,52 & Ovo de galinha & 0,18 \\
Sardinha & 1,96 & Queijo prato & 0,09 \\
Manteiga & 0,12 & Bacon & 0,8 \\
\hline
\end{tabular}

Dois estudos desenvolvidos pela Canadian Grain Commission confirmam a estabilidade da semente de linhaça armazenada sob temperatura ambiente. No primeiro estudo, as amostras foram moídas e embaladas em sacos plásticos e armazenadas por 128 dias a $23^{\circ} \mathrm{C}$. Nenhuma diferença significativa foi encontrada nos testes de peroxidase, conteúdo de ácidos graxos livres e TBA (MALCOLMSON et al., 2000). PRZYBYLKI e DAUN (2001) avaliaram a estabilidade do tocoferol da semente de linhaça armazenada in natura e verificaram que este antioxidante se mantém estável durante todo período.

Estes testes são úteis para orientação com relação ao armazenamento e processamento da farinha de linhaça. A boa estabilidade da semente de linhaça durante processamento e armazenamento sob diferentes temperaturas ainda precisa ser melhor investigada para identificação dos agentes envolvidos neste processo. 


\section{BIBLIOGRAFIA:}

1. AOAC - ASSOCIATION OF OFFICIAL ANALYTICAL CHEMISTS. Official Methods of Analysis. Washington, v. 1, p. 342, 1990.

2. ARAúJO, J. M. A. Química de Alimentos: Teoria e Prática. 3 ed. Viçosa: UFV, 2004. 478p.

3. CHEFTEL, J. C.; CHEFTEL, H.; BESANCON, P. Introduction a la bioquimica y tecnologia de los alimentos. Zaragoza; Acribia: 2000. v. 2.

4. CHEN, Z-Y.; RATNAYAKE, W.M.N.; CUNNANE, S.C. Oxidative stability of flaxseed lipids during baking, J. Am. Oil Chem. Soc. v. 71, p. 629-632, 1994.

5. CUNNANE, S. C.; GANGULI, S.; HAMADEH, M.J.; CHEN, Z-Y. High $\alpha$ linolenic acid flaxseed: some nutritional properties in humans, Br. J. Nutr. v. 69, p.443-453, 1993.

6. CUNNANE, S. C.; HAMADEH, M.J.; THOMPSON, L.U.; JENKINS, D.J.A. Nutritional Attributes of traditional flaxseed in health young adults, Am. J. Clin. Nutr. v. 61, p. 62-68, 1994.

7. CUNNANE, S. C. Dietary Sources and Metabolism of $\alpha$-linolenic Acid. In: Flaxseed in human nutrition. 2. ed. Champaign, Illinois: AOCS Press, 2003, p. 6391.

8. DAUN, J. K.; BARTHET, V. J.; CHORNICK, T. L.; DUGUID, S. Structure, Composition and Variety Development of Flaxseed. In: Flaxseed in human nutrition. 2 ed. Champaign, Illinois: AOCS Press, 2003. p. 1-40.

9. INSTITUTO ADOLFO LUTZ. Normas analíticas do Instituto Adolfo Lutz. $3^{\text {a }}$ ed. São Paulo, 1985.

10. MALCOLMSON, L.J.; PRZYBYLSKI, R.; DAUN, J.K. Storage stability of milled flaxseed, J. Am. Oil Chem. Soc. v. 77, p. 235-238, 2000.

11. MANTHEY, F. A.; LEE, R.E.; HALL, C.A. Processing and cooking effects on lipid content and stability of $\alpha$-linolenic acid in spaghetti containing ground flaxseed. J. Agric. Food Chem. v. 50, p.1668-1671, 2002.

12. MARMER, W. M.; MAXWELL, R. J. Dry column method for the quantitative extraction and simultaneous class separation of lipids from muscle tissue. Lipids. v. 5, p. 365-71. 1981.

13. MORRISON, W. R.; SMITH, L.M. Preparation of fatty acid methyl esters and dimethylacetals from lipids with boron fluoride-methanol. Journal of Lipid Research. v. 5, p. 600-608, 1964. 
14. PROSKY, L.; ASP, N.G.; FURDA, I.; DE VRIES, J. W.; SCHWEIZER, T. F. HARLAND, B. F. J. AOAC. v. 68, p. 677-679, 1985.

15. PRZYBYLSKI, R.; DAUN, J.K. Additional data on the storage stability of milled flaxseed. J. Am. Oil Chem. Soc. v. 78, p. 105-106, 2001.

16. RATNAYAKE, W.M.N.; BEHRENS, W.A.; FISCHER, P.W.F.; L'ABBE, M. R.; MONGEAU, R. BEARE-ROGERS, J.L. Chemical and nutritional studies of flaxseed (Variety Linott) in rats. J. Nutr. Biochem. v. 3, p. 232-240, 1992.

17. TORRES, E. A. F. S.; OKANI, E. T. Teste de TBA: ranço em alimentos. Rev. Nac. Carne. v. 243, p. 68-78, 1997. 


\section{CAPÍTULO 3}




\section{ANÁLISE E ESTABILIDADE DE LIGNANAS EM LINHAÇA}

\section{INTRODUÇÃO:}

Desde a descoberta das lignanas em mamíferos, há mais ou menos 20 anos, se achava que seus únicos precursores eram o diglicosídio secoisolariciresinol (SDG) e o matairesinol. Recentemente, outras lignanas vegetais foram descobertas, as quais apresentam diferentes graus de conversão. Na linhaça, o SDG é o maior precursor de lignanas mamíferas, seguido pelo matairesinol e pinoresinol, presentes em pequenas quantidades (MAZUR, 1998; MEAGHER et al., 1999). Apesar de presente na semente, o isolariciresinol não é metabolizado em lignanas mamíferas, após incubação sob 24 h com microbiota intestinal humana. Desta forma, para análise de lignanas vegetais, a maioria dos métodos se concentram na determinação do SDG.

As lignanas precisam ser extraídas da sua matriz biológica antes da sua separação e detecção por técnicas cromatográficas (HPLC e CG), o que é difícil no caso da linhaça, devido à complexidade da estrutura polimérica do SDG (BAKKE e KLOSTERMANH, 1956; FORD et al., 2001). Diferentemente de outros fitoestrógenos, como as isoflavonas, que se apresentam livremente na forma aglicona, ou como simples glicosídeos, o SDG na linhaça se apresenta na forma de polímeros, compostos por 5 resíduos de SDG interconectados por quatro resíduos de 3-hidroxil-3-metil ácido glutárico. A extração incompleta deste resíduo pode ser a causa da grande variação entre os valores de SDG encontrados na linhaça, reportados pela literatura (MAZUR el al., 1996; THOMPSON, 2003).

De forma geral, os métodos utilizados para análise de lignanas em alimentos utilizam enzimas, hidrólise ácida ou básica ou suas combinações, antes e depois de 
sua extração com metanol, dioxano/etanol, éter, acetato etílico, hexano ou acetonitrila. Em alguns casos, a fermentação in vitro vem sendo utilizada para separar o SDG do polímero, e também para metabolizá-lo em lignanas mamíferas, que são depois analisadas (THOMPSON, 2003).

Cada método possui vantagens e desvantagens. Na fermantação in vitro, por exemplo, outros compostos podem ser transformados em lignanas mamíferas, além do SDG. Por outro lado, é possível saber a quantidade de lignanas na planta capaz de ser convertida fisiologicamente, in vivo, em lignanas mamíferas. Este método foi mais amplamente utilizado em 1991, mas diferentes amostras de colônias bacterianas e sua viabilidade para fermentação in vitro podem alterar significativamente os resultados, sendo inviável a comparação de resultados entre diferentes colônias.

Por outro lado, métodos que utilizam hidrólise enzimática, ácida e básica, possuem a vantagem de quantificar diretamente os precursores de lignanas. O conteúdo de SDG encontrado, utilizando-se a hidrólise ácida ou básica é muitas vezes maior do que o obtido pelo método de fermentação in vitro ou quando se realiza somente a hidrólise enzimática. Isto indica, que a hidrólise enzimática não é capaz de isolar todo o SDG da sua matriz e que a fermentação in vitro também não é capaz de converter todos os precursores em lignanas mamíferas após incubação por 24 horas. No entanto, muitas análises realisadas na semente de linhaça mostram que os resultados obtidos utilizando-se a hidrólise enzimática (ß-glucoronidase) são muitos próximos e estão associados ao total de lignanas mamíferas (enterodiol e enterolactonas) produzidos pela fermentação in vitro. Portanto, apesar dos valores de SDG obtidos neste método enzimático serem menores, eles parecem equivaler ao total que pode ser metabolisado in vivo (THOMPSON, 2003). 


\subsection{ANÁLISES DE LIGNANAS MAMÍFERAS:}

Alguns dos mais recentes métodos para determinação de lignanas em amostras de urina, plasma e tecidos são bastante similares aos utilizados em alimentos. Neste caso, as lignanas estão geralmente conjugadas ao ácido glucorônico ou sulfítico. No entanto, não podem ser diretamente analisadas na forma conjugada, pela ausência de padrões para estas formas (THOMPSON, 2003).

Normalmente, as agliconas são purificadas através de uma reação com uma solução tampão seguida por uma separação, em que se utiliza colunas para extração da fase sólida (C18 Sep-Pak cartriges). Elas também podem ser extraídas pela combinação de solventes (acetato etílico e éter). Em seguida são analisadas por cromatografia gasosa, com detector espectrômetro de massas (GC-MS) ou por cromatografia líquida (LC) com diferentes detectores. O GC-MS vem sendo utilizado há mais de 20 anos, devido a especificidade e sensibilidade para detectar níveis abaixo de 0,1 nM, sendo a técnica mais usada atualmente (ADLERCREUTZ, 1993). Um padrão interno é adicionado à amostra extraída para formação de compostos derivatizados dos trimetilsilil que serão então injetados no GC-MS. Este procedimento consome bastante tempo e trabalho com procedimentos para limpeza, hidrólise e derivatização para volatização das amostras. Desta forma, torna-se difícil aplicar esta técnica para estudos populacionais, ou mesmo clínicos onde o número de amostras é muito grande. Nestes casos, o método de cromatografia líquida possui a vantagem de ser mais simples, por não requerer um procedimento de limpeza tão extenso e, em muitos casos, a amostra pode ser injetada logo após extração. Tanto a forma aglicona, quanto as lignanas conjugadas, podem ser analisadas, pois não 
precisam ser volatilizadas. Apesar de ser utilizado para estudos epidemiológicos, devido ao seu menor custo operacional e de equipamento, o método LC com detector ultra-violeta, não pode ser utilizado em pesquisas clínicas, nas quais se precisa medir o nível basal de lignanas de pacientes ocidentais, pois nestes casos sua concentração é muito baixa, e a sensibilidade e seletividade do detector não permitem sua identificação.

Muitos métodos vêm sendo desenvolvidos para análise de lignanas em alimentos, urina, plasma e tecidos. Cada um deles possui vantagens e desvantagens e a escolha do método irá depender da sua concentração e da amostra.

\section{MÉTODOS}

\subsection{ANÁLISE DE LIGNANAS EM ALIMENTOS POR GC/MS:}

Estas análises foram realizadas durante o período de estágio de doutorado, no Laboratório sob coordenação da Professora Lilian U. Thompson, no Departamento de Ciências Nutricionais da Faculdade de Medicina da Universidade de Toronto, Canadá.

O procedimento inclui extração da amostra, hidrólise alcalina, extração em fase sólida, hidrólise enzimática e extração em fase sólida. Este procedimento é aplicado para amostras de alimentos desengordurados com alto conteúdo de lignanas na forma de polímeros.

Em amostras com conteúdo de lipídeos superior a 10\%, como as sementes de linhaça integrais, faz-se necessário o desengorduramento prévio. Para isto, a amostra moída foi desengordurada com hexano em uma proporção de 1:5, amostra:hexano, 
em duas extrações de 1 hora cada com uma lavagem final de 30 minutos. A partir desta etapa as amostras foram extraídas e analisadas de acordo com o procedimento a seguir.

a) Extração: $250 \mathrm{mg}$ da amostra desengordurada foi extraída com metanol:água (70:30, v/v, $5 \mathrm{~mL}$ ) em tubos de plástico tampados, colocados em banho maria $\left(60-70^{\circ} \mathrm{C}\right)$, por duas vezes. $\mathrm{O}$ extrato foi coletado e ao final o resíduo foi lavado com o mesmo solvente e adicionado aos extratos iniciais. O volume total final foi de $12 \mathrm{~mL}$.

b) Hidrólise básica e extração em fase sólida: uma alíquota $(0,5-1 \mathrm{~mL}$, 1/24-1/12) do extrato foi tomada e o solvente evaporado com auxílio de um rota-vapor a $60^{\circ} \mathrm{C}$. O resíduo foi então submetido a hidrólise básica ( 5 $\mathrm{mL}$ de $\mathrm{NaOH} 1 \mathrm{~N}$ ). Após 3 horas sob̉ temperatura ambiente, a hidrólise está completa, e amostra foi então neutralizada com ácido acético (5 mL 1 N) para $\mathrm{pH} 7,0$. O sal formado foi removido da amostra utilizando uma coluna reversa SPE C18 (Octadecyl C18/14\%, $200 \mathrm{mg} / 3 \mathrm{~mL}$ ) que foi preparada previamente com $2 \times 2,5 \mathrm{~mL}$ de uma solução metanol/clorofórmio $(1: 1, \mathrm{v} / \mathrm{v})$, seguido por $2 \times 2,5 \mathrm{~mL}$ de metanol e a mesma quantidade de água. A amostra hidrolisada foi passada pela coluna condicionada que foi em seguida lavada com água $(2 \times 2,5 \mathrm{~mL})$ para remoção do sal. A fração foi eluída com $2 \times 2 \mathrm{~mL}$ de metanol e o solvente foi removido no rota-vapor abaixo de $60{ }^{\circ} \mathrm{C}$.

c) Hidrólise enzimática e extração em fase sólida: o resíduo acima foi submetido a hidrólise enzimática "over-night" com $5 \mathrm{~mL}$ de $0,1 \mathrm{M}$ da solução tampão acetato de sódio $(\mathrm{pH}=4,5)$ e $100 \mu \mathrm{L}$ de $50 \%(\mathrm{v} / \mathrm{v})$ de $\beta$ - 
glucuronidase em banho maria de $37^{\circ} \mathrm{C}$. A amostra hidrolisada foi passada pela coluna SPE preparada e depois lavada com água $(2 \times 2,5 \mathrm{~mL})$ para remoção do sal. A fração foi eluída com $2 \times 2 \mathrm{~mL}$ de metanol. O metanol foi removido no rota-vapor abaixo de $60^{\circ} \mathrm{C}$ e em seguida a amostra foi dissolvida em $2 \times 500 \mu \mathrm{l}$ de metanol.

d) Derivatização: a solução metanólica foi adicionada de $100 \mu \mathrm{L}$ da solução padrão interna ( $5 \alpha$-Androstane- $3 \beta, 17 \beta$-diol, $50 \mu \mathrm{g} / \mathrm{mL}$ ) e seca sob gás $\mathrm{N}_{2}$ e em seguida foi derivatizada com $100 \mu \mathrm{L}$ do reagente Tri-Sil (HMDS/TMCS em pyridine 2:1:10) por 30 minutos à $60^{\circ} \mathrm{C}$. $\mathrm{O}$ agente foi removido sob gás $\mathrm{N}_{2}$ e a amostra com trimetilsil foi ressuspensa em hexano antes da injeção no CG-MS.

e) Análise no CG-MS: as análises foram realizadas em cromatógrafo gasoso acoplado ao espectrômetro de massa Agilent 5973 MSD equipado com HP-5ms coluna capilar $(25 \mathrm{mx} 0,12 \mathrm{~mm} \times 0,25 \mu \mathrm{m})$. O fluxo do gás hélio foi de $1 \mathrm{~mL} / \mathrm{min}$., a temperatura programada para $100^{\circ} \mathrm{C}(1 \mathrm{~min})$ a uma velocidade de $25^{\circ} \mathrm{C} / \mathrm{min}$ até $280^{\circ} \mathrm{C}$ (em $17 \mathrm{~min}$ ). As temperaturas de injeção foram 150,230 e $280^{\circ} \mathrm{C}$ e o volume injetado de $1 \mu \mathrm{L}$.

Este procedimento para análise em alimentos leva em torno de 3 dias: um primeiro dia basicamente para extração, outro para hidrólise básica e enzimática, e o terceiro para derivatização e injeção da amostra no CG-MS. 


\section{RESULTADOS:}

As análises de lignanas foram realizadas em 6 diferentes amostras de linhaça comercialmente vendidas no mercado nacional. A metade das amostras constituída de sementes de linhaça integral ( 2 amostras comerciais "A" e "B"), e a outra metade de uma farinha de linhaça, parcialmente, desengordurada (três lotes da marcacomercial "C"). Todas as amostras foram moídas e desengorduradas com hexano (1:5) para comparação final dos resultados em uma amostra sem lipídeos. Além disto, determinou-se o conteúdo de lipídeos nas amostras por Soxhlet, com éter de petróleo, e os valores estão apresentados na Tabela 1 abaixo.

Tabela 1 - Conteúdo de lipídeos nas amostras da semente e farinha de linhaça.

\begin{tabular}{ccccccc}
\hline Amostras & A1 & A2 & B1 & C1 & C2 & C3 \\
\hline $\begin{array}{c}\text { \% Lipídeos } \\
\text { extraídos por } \\
\text { hexano }\end{array}$ & 31,5 & 34,0 & 33,5 & 8,0 & 12,5 & 14,6 \\
$\begin{array}{c}\text { \% Lipídeos } \\
\text { extraídos com }\end{array}$ & 37,6 & 38,9 & 37,8 & 8,1 & 14,1 & 16,8 \\
$\begin{array}{c}\text { éter de petróleo } \\
\text { em Soxllet }\end{array}$ & & & & & & \\
\hline
\end{tabular}

As amostras "A" e " $\mathrm{B}$ " são integrais e por isto apresentaram um maior conteúdo de lipídeos. Ao compararmos os dois resultados, pode-se perceber que a extração com hexano possui uma eficiência de, aproximadamente, $90 \%$ do total extraído com éter de petróleo no Soxhlet. Deste modo, não podemos assumir que todas os lotes analisados possuem o mesmo teor de lipídeos após extração, podendose esperar que as três primeiras estarão mais diluídas por conterem uma quantidade maior de lipídeos do que as outras amostras. 
A tabela 2 contém os valores do diglicosídeo secoisolariciresinol nas amostras analisadas. Os valores detectados na faixa de $10^{-9} \mathrm{~g}$. A partir dos dados como, peso da amostra utilizada e peso molecular do SDG, calcula-se sua concentração.

Tabela 2 - Conteúdo de SDG em diferentes amostras nacionais de linhaça e farinha de linhaça.

\begin{tabular}{lcccccc}
\hline Amostras & A1 & A2 & B1 & C1 & C2 & C3 \\
\hline $\begin{array}{lccccc}\text { Secoisolariciresinol } \\
\text { (ng) }\end{array}$ & 392796,6 & 164016,5 & 479819,2 & 483245,5 & 156485,8 & 532318,2 \\
$\mathbf{n g} / \mathbf{g}$ & 18837283,7 & 7868072,6 & 23019811,2 & 23137937,2 & 7500068,8 & 26597290,4 \\
$\mathbf{m g} / \mathbf{g}$ & 18,837 & 7,868 & 23,020 & 23,138 & 7,500 & 26,597 \\
$\mathbf{m m o l} / \mathbf{g}$ & 0,052 & 0,022 & 0,064 & 0,064 & 0,021 & 0,073 \\
SDG (mg/g) & 35,692 & 14,908 & 43,617 & 43,841 & 14,211 & 50,396 \\
\% SDG nas & 3,569 & 1,491 & 4,362 & 4,384 & 1,421 & 5,040 \\
amostras deseng. & & & & & & \\
\% SDG nas & 2,45 & 0,98 & 2,9 & 4,04 & 1,245 & 4,3 \\
amostras originais & & & & & & \\
\hline
\end{tabular}

As amostras A2 e C2 apresentam teores de SDG significativamente menores que as outras amostras. A análise é muito sensível a pequenos erros na corrida analítica e desta forma, em alguns casos, como da amostra C3, que será utilizada no ensaio clínico, as análises foram feitas em triplicata. De qualquer modo, pode-se perceber que existe uma diferença de mais de $70 \%$ nos valores de SDG entre as amostras analisadas.

Para verificar a estabilidade das lignanas ao processamento na forma de pães, utilizou-se a amostra "C3" obtido para realização do ensaio clínico, que foi 
armazenado sob refrigeração, durante todo período de estudo. A tabela abaixo, mostra a variação nos valores de SDG nas diversas etapas de produção do pão. $\mathrm{Na}$ massa, antes e após o crescimento, após o cozimento e no pão torrado, para o caso de vir a ser consumido nesta forma. Todas as amostras foram desidratadas a frio, em um liofilizador, antes da análise para que não sofressem alterações no conteúdo de SDG.

Tabela 3 - Efeito do processamento no conteúdo de SDG nos pães.

\begin{tabular}{|c|c|c|c|c|}
\hline Amostras & 1 & 2 & 3 & 4 \\
\hline Secoisolariciresinol (ng) & 58445,55 & 42935,51 & 38359,68 & 33931,19 \\
\hline $\mathrm{ng} / \mathrm{g}$ & 2772005,6 & 2037195,8 & 1819900,9 & 1609478,3 \\
\hline $\mathbf{m g} / \mathrm{g}$ & 2,772 & 2,037 & 1,820 & 1,609 \\
\hline $\mathrm{mmol} / \mathrm{g}$ & 0,008 & 0,006 & 0,005 & 0,004 \\
\hline SDG $(\mathbf{m g} / \mathrm{g})$ & 5,252 & 3,860 & 3,448 & 3,050 \\
\hline $\begin{array}{l}\% \text { SDG amostras } \\
\text { analisadas }\end{array}$ & 0,525 & 0,386 & 0,345 & 0,305 \\
\hline$\%$ SDG base seca & 0,552 & 0,403 & 0,359 & 0,320 \\
\hline $\begin{array}{l}\% \text { SDG nas amostras } \\
\text { integrais }\end{array}$ & 0,255 & 0,183 & 0,1745 & 0,18 \\
\hline
\end{tabular}

Por ser o pão um produto que sofre fermentação a idéia de se medir o conteúdo de SDG na massa antes e após crescimento teve o intuito de verificar se a ação das leveduras e suas enzimas interferem de alguma forma na transformação de SDG em enterodiol e enterolactonas. Assim como ocorre com as isoflavonas, que em produtos fermentados (tofu) se apresentam na forma de agliconas, mais biodisponíveis, o objetivo foi verificar se as lignanas se transfomam após este tipo de fermentação. 
A partir dos cromatogramas pode-se observar que não houve tranformação de SDG em enterodiol ou enterolactonas após crescimento da massa, desta forma a diferença entre as etapas 1 e 2 pode ser devido a corrida analítica.

De acordo com os valores apresentados na Tabela 3, pode-se perceber uma perda de cerca de $10 \%$ em cada etapa do processamento avaliada.

Após o cozimento, $89 \%$ do conteúdo de SDG foi mantido no produto e a retenção pela torragem do pão foi da mesma ordem (89\%). WESTCOTT e MUIR (1996, 2000) testaram o efeito da adição de SDG puro em pães e mostraram uma estabilidade de $99,5 \%$ após cozimento, demonstrando a boa estabilidade deste componente ao processamento. Em outro trabalho, estes mesmos autores, adicionaram diferentes quantidades de farinha de linhaça $(4,8$ e $12 \%)$ aos pães e conseguiram recuperar apenas de 72 a $75 \%$ de SDG após cozimento. Outros autores (NESBITT e THOMPSON, 1997; RICKARD et al.,1998) demonstraram que valores equivalentes ao adicionado de lignanas foram obtidos após processamento a $190^{\circ} \mathrm{C} \mathrm{e}$ $205^{\circ} \mathrm{C}$. Além disto, verificaram que o conteúdo de lignanas excretadas na urina de 9 mulheres que consumiram linhaça crua ou assada na forma de pães e muffins foi o mesmo. Estes estudos sugerem que o SDG é estável ao processamento térmico.

Na formulação do pão analisado, substituiram-se $27 \%$ do total de farinha de trigo pela farinha de linhaça, com 4,3\% de SDG. Essa porcentagem cai para 11,5\% de linhaça, considerando-se todos os ingredientes da massa. Desta forma, poderíamos esperar algo em torno de $0,49 \%$ de SDG na massa e o valor encontrado foi de $0,255 \%$ (amostra seca), quase metade do esperado. Considerando-se que a massa possui um conteúdo médio de umidade de $52 \%$ e que a amostra foi analisada após secagem em liofilizador, o valor esperado seria de $0,24 \%$. Estas estimativas e 
cálculos só devem ser utilizados no caso de serem conhecidos os valores de SDG na semente e não existir meio de avaliar no produto final. Neste caso, o importante é que pouco se perdeu na massa após cozimento, o que confirma resultados de outros estudos que mostram que o SDG é estável ao processamento térmico. 


\section{BIBLIOGRAFIA}

1. ADLERCREUTZ, H.; et al. Quantitative determination of lignans and isoflavones in plasma of ominovirous and vegetarianas women by isotope dilution chrotographymass spectrometry. Scand. J. Clin. Lab. Invest., v. 53, p. 5-18, 1993.

2. BAKKE, J.E. \& KLOSTERMANH.J. A new diglucoside from flaxseed, N. Dak. Acad. Sci., v. 10, p.18-22, 1956.

3. FORD, J. D. et al. Biosyntetic pathway to the cancer chemoprotective secoisolaresinol in flaxseed. J. Nat. Prod., v. 64, p. 1388-1397, 2001

4. HORN ROSS, P. L. et al. Assessing phytoestrogen exposure in epidemiologic studies: development of a data base (United States), Cancer Causes Control., v. 11, p. 289-298, 2000.

5. JOHNSSON, P.; KAMAL-ELDIN, A.; LUNDGREN, L. N.; AMAN, P., HPLC Method for analysis of secoisolariciresinol diglucoside in flaxseed, J. Agric. Food Chem., v. 48, p. 5216-5219, 2000.

6. MAZUR, W. Phytoestrogen content in foods, Bailliere's Clin. Endocrinol. Metab., v. 2, p. 729-742, 1998.

7. MAZUR, W. M.; FOTSIS, T.; WAHALA, K.; OJALA, S.; ADLERCREUTZ, H., Isotope-dilution Gas-cromatographic Mass-spectrometric Method for the determination of isoflavonoids, coumestrol and lignans in food samples, Anal. Biochem., v. 233, p. 169-180, 1996.

8. MEAGHER, L. P.; BEECHER, G. R.; FLANAGAN, V. P.; LI, B. W. Isolation and characterization of the lignans, Isolariciresinol, pinoresinol, in flaxseed meal, $\mathbf{J}$. Agric. Food Chem., v. 47, p. 3173-3180, 1999.

9. MUIR, A.D.; WESCOTT, N.D. Quantification of the lignan seicosolariciresinol diglicoside in baked goods containig flax seed or flax meal. J. Agric. Food Chem., v. 48 , p. $4048-4052,2000$.

10. NESBITT, P.D., THOMPSON, L.U. Lignans in homemade and Commercial products containing flaxseed, Nutr. Cancer, v. 29, p.222-227, 1997.

11. RICKARD, S.E.; JENAB, M.; TOU, J.L.C.; NESBITT, P.D. AND THOMPSON, L.U. Anticancer effects and avaiability of flaxseed lignans, in Proceedings of the $\mathbf{5 7}^{\text {th }}$ Flax Institute of United States, Flax Institute, Fargo, North Dakota, pp. 8-14, 1998.

12. THOMPSON, L. U.; RICKARD, S. E.; CHEUNG, F. Variability in anticancer lignan levels in flaxseed, Nutr. Cancer, v. 27, p. 26-30, 1997. 
13. THOMPSON, L. U. Analysis and bioavailability of lignans. In: Flaxseed in human nutrition. 2. ed. Champaign, Illinois: AOCS Press, 2003, p. 92-116.

14. WESTCOTT, N. D.; MUIR, A. D., Variation in flaxseed lignan concentration with variety, location and year, in: Proceedings of the $56^{\text {th }}$ Flax Institution of the United States, Fargo, North Dakota, pp. 77-85, 1996. 


\section{CAPíTULO 4}




\section{DESENVOLVIMENTO DOS PÃES - LINHAÇA E PLACEBO}

\section{INTRODUÇÃO}

A preeminência do pão na cultura antiga é também decorrente de uma ciência dietética que coloca o pão no ápice da escala de valores nutricionais (FLANDRIN e MONTANARI, 1998). De grande importância econômica, o segmento de panificação no Brasil é responsável por um faturamento de, aproximadamente, U\$ 16 bilhões anuais. A mão-de-obra direta empregada pelo setor gira em torno de $580 \mathrm{mil}$ pessoas. É, entretanto, um mercado que encontra grande margem para crescimento, visto que o nosso consumo anual per capita é de $27 \mathrm{Kg}$, sendo a recomendação da OMS de $60 \mathrm{Kg} /$ pessoa/ano (ANÁLISE SETORIAL, 1999; ABIP, 2002).

Nesta tendência, o investimento no desenvolvimento de novos produtos é alto e visa atender consumidores cada vez mais informados e preocupados com a saúde. Uma pesquisa internacional realizada pela Nielsen (2005) mostra que, na América Latina, a média de pessoas que compram regularmente pães com ingredientes funcionais é de $26 \%$. Este é um mercado que cresceu rapidamente nos últimos anos e de forma bastante dinâmica dentro da indústria de alimentos. No setor de panificação, este mercado mostra um grande potencial para crescimento, na medida em que as empresas procuram novas formas de agregar valor e diferenciar seus produtos, frente à baixa margem de lucro dos produtos convencionais.

De acordo com a Portaria $n^{\circ} 15$ da ANVISA, para alegação de propriedade funcional e de saúde de um alimento, deve ser apresentado àquela autarquia um relatório técnico-científico com a descrição completa de seus ingredientes funcionais, além de evidências científicas que comprovem os benefícios alegados, por meio de 
ensaios clínicos e bioquímicos e de estudos epidemiológicos embasados na literatura científica sobre o alimento em questão (BRASIL ${ }^{\text {a,b }}, 1999$ ).

A substituição parcial da farinha de trigo por outras de maior valor nutritivo vem sendo prática constante na diversificação destes produtos. Nesta mesma tendência, uma alternativa seria o desenvolvimento de produtos com fins específicos, como um pão rico em fitoestrógenos, para mulheres no climatério.

A linhaça é a maior fonte de lignanas (fitoestrógeno) e pode ser obtida na forma de farinha parcialmente desengordurada, o que facilita sua incorporação em produtos de panificação. Por ser rica em ômega 3, seu principal produto comercial é o óleo, e o farelo restante possui um baixo custo, sendo uma ótima alternativa para estes produtos, pois reserva grande parte das lignanas, presentes na parte fibrosa, fibras solúveis, parte do ácido graxo $\alpha$-linolênico e proteínas de origem vegetal.

Neste caso, a pesquisa de fontes alternativas de matéria-prima, como a linhaça, é importante não somente pelo apelo nutricional, mas também pela possibilidade de divulgar e, conseqüentemente, estimular sua produção, ajudando a diminuir a dependência daquelas matérias-primas, que possuem um grande poder regulador sobre o mercado, como o trigo (ABIP, 2002).

Desta forma, o objetivo deste trabalho foi desenvolver um pão de fôrma, substituindo parte da farinha de trigo pela farinha de linhaça, e verificar o efeito do processamento térmico sobre os teores de lignanas vegetais. Para atender à legislação e testar os efeitos do consumo deste pão sobre os sintomas climatéricos de mulheres na pós-menopausa foi desenvolvida, também, uma formulação controle a base de farelo de trigo e cevada, com conteúdo de macronutrientes e aparência similares ao pão de linhaça (teste). 


\section{MATERIAL E MÉTODOS}

\subsection{MATERIAL}

A farinha de linhaça utilizada foi obtida da Indústria Pazze Ltda, na forma de farelo parcialmente desengordurado a frio, com $16,8 \%$ de lipídeos. Para maximizar o conteúdo da farinha de linhaça na formulação foi necessária adição de glúten (8\%), visando melhorar as características panificáveis desta mistura rica em fibras.

Para o desenvolvimento do pão controle foram utilizados o farelo de trigo (fonte de fibras) e a cevada torrada moída (ajuste da coloração) numa proporção necessária para o obtenção de um produto similar ao de linhaça, em termos de macronutrientes e aparência.

\subsection{MÉTODOS}

Os pães foram desenvolvidos e produzidos na padaria industrial da Fundação de Desenvolvimento da Panificação e Confeitaria (FUNDIPAN). A formulação desenvolvida para os dois pães encontra-se na Tabela 1, a seguir. 
Tabela 1. Formulação dos pães de fôrma.

\begin{tabular}{lcc}
\hline Ingredientes & Formulação linhaça & Formulação controle \\
\hline Farinha (trigo + linhaça)* & $100^{*}$ & 0 \\
Mix (trigo + farelo + cevada)** & 0 & 100 \\
Açúcar & 5,5 & 4,0 \\
Sal & 2 & 2 \\
Óleo & 5 & 10 \\
Melhorador & 1 & 1 \\
Fermento seco instantâneo & 2 & 2 \\
Água & 80 & 58 \\
Glúten (80\% pureza) & 8 & 0 \\
\hline Total & 203,5 & 177
\end{tabular}

* proporção: 70:30, ** proporção: 84:14:2

Os pães, tipo forma, foram produzidos em masseira semi-rápida com duas velocidades (35 rpm e $240 \mathrm{rpm}$ ). Após atingir o ponto de véu, a massa foi dividida em porções de 800 gramas, modeladas e colocadas para fermentar em formas apropriadas em câmara de fermentação $\left(33^{\circ} \mathrm{C}\right.$ por 45 minutos). Foram assados em forno com circulação de ar (turbo) à $160{ }^{\circ} \mathrm{C}$ por 45 minutos, com vapor. Após 24 horas de resfriamento, foram fatiados e embalados em porções diárias, com duas fatias de pão por embalagem. As embalagens utilizadas foram de poliéster e polietileno douradas, que não permitiam a identificação do conteúdo. Cada embalagem contém, em média, 80 gramas de pão/dia. 


\subsubsection{Análises Físicas}

O volume específico dos pães foi determinado pelo deslocamento de sementes de painço, dividindo-se seu volume $\left(\mathrm{cm}^{3}\right)$ pelo peso $(\mathrm{g})$, segundo metodologia proposta por El-Dash (1978).

As características viscoelásticas (força geral do glúten, tenacidade e extensibilidade) das duas misturas de farinha foram determinadas no Alveógrafo de Chopin utilizando o método $\mathrm{n}^{\circ}$ 54-30 da AACC (1995), através da pesagem de $250 \mathrm{~g}$ de farinha e volume de água corrigido de acordo com o teor de umidade.

\subsubsection{Análises Químicas}

A composição centesimal dos pães e das farinhas foi determinada de acordo com a metodologia descrita nas Normas Analíticas do Instituto Adolfo Lutz (1985): umidade por dessecação a $105^{\circ} \mathrm{C}$ até peso constante, cinzas por incineração do alimento em mufla a $550^{\circ} \mathrm{C}$ até peso constante, proteína pela técnica micro-Kjeldhal, os lipídeos em extrator Soxhlet (INSTITUTO ADOLFO LUTZ, 1985) e as fibras dietéticas pelo método de Prosky (1989) e carboidratos determinados por diferença.

Para verificar o efeito do processamento sobre o teor de lignanas e sua estabilidade ao armazenamento, as amostras foram extraídas em solução metanólica (70:30) e submetidas à hidrólise básica $(5 \mathrm{~mL}$ de $\mathrm{NaOH}, 1 \mathrm{~N})$ por 3 horas. Após neutralização da amostra com ácido acético $(1 \mathrm{~N})$, o sal foi removido em coluna reversa SPE C18 (Octadecyl C18/14\%, $200 \mathrm{mg} / 3 \mathrm{~mL}$ ). Em seguida, foram submetidas à hidrólise enzimática "over-night", com $5 \mathrm{~mL}$ de solução tampão e $\beta$ - 
glucuronidase, em banho-maria a $37^{\circ} \mathrm{C}$ e passada pela coluna reversa novamente antes da sua derivatização com Tri-Sil. As amostras dissolvidas em hexano foram analisadas no espectrômetro de massa Agilent 5973 MSD, acoplado ao cromatrógrafo gasoso Agilent 6890, equipado com HP-5ms coluna capilar $(25 \mathrm{mx} 0,12 \mathrm{mmx} 0,25 \mu \mathrm{m})$. O fluxo do gás helium foi de $1 \mathrm{~mL} / \mathrm{min}$., com temperatura programada para $100^{\circ} \mathrm{C}(1 \mathrm{~min})$ a uma velocidade de $25^{\circ} \mathrm{C} / \mathrm{min}$ até $280^{\circ} \mathrm{C}$ (em 17 min). As temperaturas de injeção foram 150,230 e $280^{\circ} \mathrm{C}$ e o volume injetado de 1 $\mu \mathrm{l}$ (THOMPSON, 1991).

\section{RESULTADOS E DISCUSSÃO}

De acordo com o Regulamento Técnico de Identidade e Qualidade para farinha de trigo (BRASIL, 2005), as farinhas destinadas à panificação (Tipo 1) devem apresentar valores de umidade inferiores a $15 \%$ e cinzas até $0,8 \%$. O teor de proteínas indicado deve estar acima de $8 \%$. As análises químicas das misturas de farinha, bem como da farinha de trigo base, estão apresentadas na Tabela 2, juntamente com os parâmetros físicos. Os parâmetros físicos obtidos no Alveógrafo de Chopin foram: tenacidade $(\mathrm{P})$, que mede a sobrepressão máxima exercida na expansão da massa (mm); a extensibilidade (L), que mede o comprimento da curva $(\mathrm{mm})$ e a energia de deformação da massa (W), que corresponde ao trabalho mecânico necessário para expandir a bolha até ruptura $\left(10^{-4} \mathrm{~J}\right)$. 
Tabela 2. Análises físico-químicas da farinha de trigo e das misturas.

\begin{tabular}{lccc}
\hline & Farinha de trigo & Mix de linhaça* & Mix controle** \\
\hline umidade \% & $14,0 \pm 0,09$ & $11,6 \pm 0,19$ & $13,2 \pm 0,002$ \\
proteína \% & $14,8 \pm 1,22$ & $25,2 \pm 0,11$ & $13,9 \pm 0,09$ \\
cinzas \% & $0,6 \pm 0,03$ & $1,7 \pm 0,000$ & $1,2 \pm 0,02$ \\
\hline mL de água & 129 & Alveografia & 133 \\
P (mm) & 98 & 140 & 137 \\
L (mm) & 81 & 223 & 23 \\
W (10 & & 18 & 143 \\
\hline
\end{tabular}

* farinha de trigo + farinha de linhaça + glúten, ** farinha de trigo + farelo + cevada

A farinha de trigo, utilizada como base nas formulações, atende a todos os requisitos da legislação no que se refere ao conteúdo de umidade, cinzas e proteínas. A umidade é importante por ser um dos principais fatores de aceleração das reações químicas e enzimáticas. Com relação ao teor de proteínas, a mistura com linhaça apresenta valores acima do recomendado para panificação (11,5 a 14,5\%), devido ao elevado teor de proteínas da farinha de linhaça $(\sim 30 \%)$ e do glúten adicionado com a finalidade de melhorar a capacidade de formação da massa e o volume final.

A adição de farinhas ricas em fibras e pobres em glúten (gliadina e glutenina) diminuiu de forma considerável a força geral do glúten (W) e a extensibilidade (L) das misturas em relação à farinha de trigo comum. Por outro lado, aumentou 
significativamente a resistência à expansão das massas (P). Para panificação, uma relação P/L próxima de 1 é o ideal, por fornecer à massa capacidade de expandir com a produção de gases, durante a fermentação, e elasticidade necessária para resistir a expansão, garantindo a forma arredondada dos pães. A farinha mix de linhaça, apesar de apresentar uma força (W) maior que a farinha mix controle, apresentou uma relação P/L próxima de 12 frente à relação 5 da controle. Segundo Gutkoski (2002), é esperado que o volume do pão aumente proporcionalmente com o aumento da força geral do glúten (W); no entanto, a maior relação $\mathrm{P} / \mathrm{L}$ desta mistura vai refletir no menor volume final destes pães (Tabela 3), como conseqüência da maior resistência à expansão $(\mathrm{P})$ apresentada por esta mistura.

Tabela 3. Rendimento e volume específico dos pães.

\begin{tabular}{lcc}
\hline & Pão de linhaça & Pão controle \\
\hline Peso antes de assar $(\mathrm{g})$ & 800 & 800 \\
Peso após forneamento(g) & $696,2 \pm 2,3$ & $707,5 \pm 1,9$ \\
Rendimento & $87,0 \%$ & $88,4 \%$ \\
Volume médio $\left(\mathrm{cm}^{3}\right)$ & $1895 \pm 64,7$ & $2119 \pm 58,5$ \\
Volume específico $(\mathrm{L} / \mathrm{Kg})$ & $2,7 \pm 0,1$ & $2,9 \pm 0,1$ \\
\hline
\end{tabular}

A análise da composição centesimal da farinha de linhaça Pazze, parcialmente desengordurada, e dos pães desenvolvidos está apresentada na Tabela 4 a seguir. 
Tabela 4. Composição centesimal da farinha de linhaça e dos pães.

\begin{tabular}{lccc}
\hline \hline Composição & \multicolumn{3}{c}{ Amostras } \\
\cline { 2 - 4 } Centesimal & Farinha de Linhaça & Pão de linhaça & Pão controle \\
\hline Umidade (\%) & 9,5 & 37,3 & 33,5 \\
Lipídeos (\%) & 15,2 & 1,4 & 1,6 \\
Proteína (\%) & 30,2 & 15,4 & 8,6 \\
Cinzas (\%) & 4,4 & 2,7 & 1,86 \\
Fibras (\%) & 44,9 & 11,2 & 10,9 \\
Carboidratos (\%)* & - & 32,01 & 43,54 \\
\hline \hline
\end{tabular}

* O percentual carboidratos foi calculado pela diferença entre a soma da umidade, lipídeos, proteína, cinzas e fibras e 100.

Como pode ser observado, o conteúdo de fibras e lipídeos dos pães ficou similar, não sendo possível o ajuste das proteínas, em virtude da composição da farinha de linhaça e do glúten adicionado. No entanto, este componente não tem tanta importância para o nosso estudo, visto que os componentes ativos a serem estudados da linhaça estão presentes na parte fibra (lignanas) e, eventualmente, na fração etérea por ser rica em ômega 3 .

Para verificar o efeito do processamento sobre o teor de lignanas, as análises foram realizadas na pré-mistura antes do crescimento, na massa antes e após cozimento e no pão torrado, para o caso do consumo final nesta forma (Figura 1). Todas as amostras foram liofilizadas previamente à corrida analítica. 


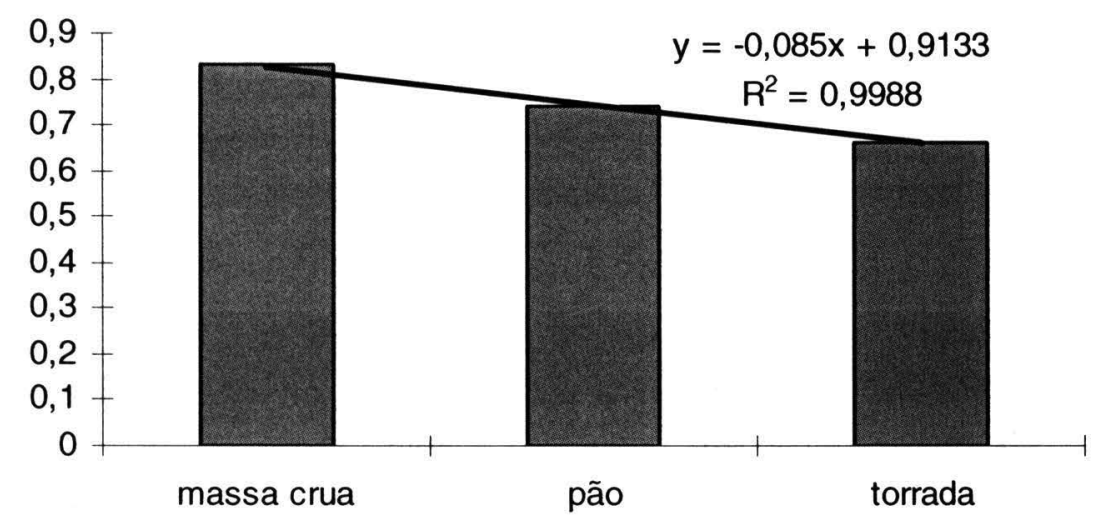

Figura 1. Efeito do processamento térmico sobre o teor de lignanas (base seca).

Como se pode perceber, o processamento da linhaça na forma de pães, pouco interfere no conteúdo de lignanas vegetais, verificando-se perda de cerca de $10 \%$ entre as etapas, que se mostraram relativamente estáveis ao processamento térmico nesta matriz, confirmando resultados de outros estudos (HYVÄRINEN et al., 2006).

Para verificar a estabilidade das lignanas vegetais na farinha armazenada sob refrigeração e congelamento foram realizadas novas análises após o período de 1 ano. Além disto, foram feitas análises nas pré-misturas utilizadas na fabricação dos dois tipos de pães, mas o conteúdo do pão controle foi insignificante, não sendo apresentado na Tabela 5 abaixo. 
Tabela 5. Concentração de SDG na farinha de linhaça armazenada e na pré-mistura.

\begin{tabular}{lrrrr}
\hline & Farinha de linhaça & $\begin{array}{c}\text { FL armazenada } \\
\text { em geladeira }\end{array}$ & $\begin{array}{c}\text { FL armazenada } \\
\text { no freezer }\end{array}$ & Pré-mistura do pão \\
\hline Data & jur/04 & jul/05 & jul/05 & jul/05 \\
Peso $(\mathrm{g})$ & 1,007 & 0,1 & 0,1 & 0,1 \\
Volume $(\mathrm{g} / \mathrm{ml})$ & $1 / 50$ & $1 / 12$ & $1 / 12$ & $1 / 24$ \\
Seco $(\mathrm{ng} / \mathrm{g})$ & 291065,3 & 101770,9 & 55855,06 & 2326,97 \\
SDG $(\mathrm{mg} / \mathrm{g})$ & 18,199 & 15,85 & 12,16 & 0,92 \\
$\%$ SDG & 1,82 & 1,6 & 1,2 & 0,093 \\
\hline
\end{tabular}

De acordo com os valores calculados, pode-se observar uma boa estabilidade (perda de 12\%) do SDG (lignanas vegetais) quando armazenado sob refrigeração (< $\left.8^{\circ} \mathrm{C}\right)$, no período de um ano.

Sob congelamento a queda foi maior (34\%) e esta diferença pode ser explicada pelo fatọde baixas temperaturas favorecerem reações de oxidação lipídica, pela redução da atividade de água no alimento, consumindo compostos fenólicos antioxidantes, como as lignanas vegetais.

A pré-mistura (farinha de trigo:linhaça:glúten, 70:30:8) do pão de linhaça analisado continha $28 \%$ de farinha de linhaça, levando-se em consideração o glúten adicionado. Para produção do pão de fôrma utilizamos $800 \mathrm{~g}$ de massa, equivalentes a 424,5 g do mix de farinhas. Considerando-se que cada pão rende 17 fatias, temos $24,9 \mathrm{~g}$ desta pré-mistura por fatia, e $50 \mathrm{~g}$ por embalagem. Sabendo-se que na prémistura temos $0,92 \mathrm{mg} / \mathrm{g}$ de SDG, teríamos $46 \mathrm{mg}$ de lignanas por embalagem.

Desta forma, o produto desenvolvido, se consumidos 2 fatias/dia, forneceria $14 \mathrm{~g}$ da farinha de linhaça desengordurada, o equivalente a $25 \mathrm{~g}$ da semente integral (em termos de fibras e lignanas) e $46 \mathrm{mg}$ de lignanas vegetais. 
Alguns estudos clínicos, realizados para verificar os efeitos das lignanas sobre o metabolismo hormonal em mulheres, mostraram que $10 \mathrm{~g}$ da semente já são suficientes para alterar o metabolismo de estradiol (BROOKS et al., 2004). DODIN et al. (2005) estudou os efeitos da ingestão de $40 \mathrm{~g}$ de linhaça/dia sobre os sintomas climatéricos e não observou resultados significativos. Segundo THOMPSON (2005), se o efeito esperado for decorrente do consumo de lignanas, a quantidade de linhaça é menos importante do que o conteúdo deste componente, que é bastante variável entre sementes de diferentes regiões. Outro estudo recente (LEWIS et al., 2006) avaliou a ingestão de $25 \mathrm{~g}$ de linhaça dourada (50 $\mathrm{mg}$ de lignanas) sobre a qualidade de vida e a sintomatologia de ondas de calor em mulheres climatéricas e não observou diferença estatística significativa.

\section{CONCLUSÃO}

Os dois produtos desenvolvidos atingiram o objetivo inicial de ter aparência (Anexo 1) e conteúdo de macronutrientes similares, especialmente com relação ao conteúdo de fibras e lipídeos. Além disto, pode-se verificar que as lignanas vegetais são bastante estáveis ao processamento e armazenagem sob refrigeração.

Desta forma, pode-se concluir que o uso da farinha de linhaça em produtos de panificação é boa alternativa para agregar valor a estes produtos frente a consumidores cada vez mais preocupados com a saúde, por ser excelente fonte de fibras (solúveis e insolúveis), ômega 3 e lignanas. Economicamente, é também alternativa para reduzir a dependência às importações de trigo, pois permite produzir um alimento enriquecido a partir de uma matéria-prima de baixo custo (subproduto da extração do óleo de linhaça). 


\section{BIBLIOGRAFIA}

ABIP - Associação Brasileira das Indústrias de Panificação e Confeitaria - Análise do mercado de pães, 2002. [17/11/2003]. (http://www.abip.org.br)

ADLERCREUTZ, H. et al. Dietary phytoestrogens and cancer: in vitro and in vivo studies. The Journal of Steroid Biochemistry and molecular biology, v.41, p.331337.

AMERICAN ASSOCIATION OF CEREAL CHEMISTS. Approved methods of the AACC. 8.ed. Saint Paul: AACC, 1995. Paginação irregular.

ANÁLISE SETORIAL - Pães e Padarias. Gazeta Mercantil. v.1-2. Säo Paulo, 1999. $337 p$.

ANÔNIMO. Alimentos funcionais e o maravilhoso mundo dos nutracêuticos. Aditivos \& Ingredientes. n.17, p. 38-50, 2001.

ANÔNIMO. O Linho. Revista Globo Rural. n. 171, Jan., 2000.

BRASIL $^{a}$, Ministério da Saúde. Agência Nacional de Vigilância Sanitária. Resolução $\mathrm{n}^{\circ} 18$ de 30 de abril de 1999. Aprova o regulamento técnico que estabelece as diretrizes básicas para análise e comprovação de propriedades funcionais e ou de saúde alegadas em rotulagem de alimentos. Diário Oficial da União, de 03 de maio de 1999.

BRASIL ${ }^{\text {b }}$, Ministério da Saúde. Agência Nacional de Vigilância Sanitária. Resolução $\mathrm{n}^{\circ} 19$ de 30 de abril de 1999. Aprova o regulamento técnico de procedimentos para registro de alimentos com alegação de propriedades funcionais e ou de saúde em sua rotulagem. Diário Oficial da União, de 03 de maio de 1999.

BRASIL. Instrução Normativa $n^{\circ}$ 8. Regulamento Técnico de Identidade e Qualidade da Farinha de Trigo. Brasília, 02 de junho de 2005.

BROOKS, J. D.; WARD, W. E.; LEWIS, J. E. THOMPSON, L. U. Supplementation with flaxseed alters estrogen metabolism in postmenopausal women to a greates extent than does supplementation with an equal amount of soy. American Journal of Clinical Nutrition, v. 79, p. 318-325, 2004.

DODIN, S.; LEMAY, A. JACQUES, H.; LEGARE, F.; BASSE, B. The effects of flaxseed dietary supplement on lipid profile, bone mineral density and symptoms in menopausal women: a randomized, double-blind, wheat germ placebo-controlled clinical trial. Journal of Clinical Endocrinology Metabolism, v. 90, p. 1390-1397, 2005.

EL-DASH, A.A. Standardized mixing and fermentation procedure for experimental baking test. Cereal Chemistry, Saint Paul, v.55, n.4, p. 436-446, 1978. 
FLANDRIN, J.L.; MONTANARI, M. História da Alimentação. São Paulo: Estação da Liberdade, 1998. 885p.

GUTKOSKI, L. C. E JACOBSEN NETO, R. Procedimento laboratorial de panificação - Pão Tipo Forma. Ciência Rural, v. 32, n.5, 2002.

HYVÄRINEN, H.K.; et al. Effect of processing and storage on the stability of flaxseed lignan added to bakery products. Journal of Agricultural and Food Chemistry, v. 54, p. 48-53, 2006.

LEWIS, J.E.; NICKELL, L.A. et al. A randomized controlled trial of the effect of dietary soy and flaxseed muffins on quality of life and hot flushes during menopause. Menopause, v. 13, n. 4, p. 631-642, 2006.

THOMPSON, L.U. et al. Mammalian lignan production from various foods. Nutrition and Cancer, v.16, n.1, p.43-52, 1991.

THOMPSON, L. U. Flaxseed provides modest benefits for menopause-related symptoms. First to Know, maio de 2005. Disponível em: http://www.menopause.org/news/news0505.pdf, acesso em: 2006

ZERO HORA, Linhaça avança e rouba espaço do trigo. Rio Grande do Sul, 2005. Disponível em: http://www.zerohora.com.br, acesso em: outubro de 2005. 


\section{CAPítulo 5}




\section{ESTUDO RANDOMIZADO E CONTROLADO DOS EFEITOS DE PÃES DE \\ LINHAÇA SOBRE OS SINTOMAS CLIMATÉRICOS DE MULHERES NA PÓS-MENOPAUSA.}

\section{RESUMO}

Objetivos: Verificar os efeitos da ingestão diária de pães produzidos com farinha de linhaça nos sintomas climatéricos e espessura endometrial de mulheres menopausadas.

Metodologia: Ensaio clínico duplo-cego, randomizado, com controle placebo. Trinta e oito mulheres, na menopausa de 1 a 10 anos, ingeriram durante 12 semanas consecutivas, duas fatias de pão com $25 \mathrm{~g}$ de linhaça (46 mg de lignanas) ou com farelo de trigo (controle) diariamente. As variáveis de desfecho foram o número diário de ondas de calor, Índice Menopausal de Kupperman (IMK) e espessura endometrial. Foram avaliados também o perfil lipídico (colesterol total e frações: HDL, LDL e VLDL e triglicérides) e os hormônios estradiol, FSH, TSH, t4 livre no plasma. A avaliação de consumo durante o estudo foi feita através da média de 2 recordatórios de 24 horas no pré e no pós tratamento.

Resultados: Vinte pacientes no grupo de estudo e 18 no controle completaram o estudo. Nenhuma diferença estatisticamente significativa foi observada entre as características gerais das pacientes no momento inicial do estudo. Os dois grupos apresentaram redução estatística significativa nas ondas de calor e no IMK após 3 meses de tratamento, mas nenhuma diferença pôde ser verificada entre eles.

Conclusão: A administração de $46 \mathrm{mg} /$ dia de lignanas na forma de pães não é mais efetiva que o placebo na redução das ondas de calor e do IMK. Nenhum efeito foi verificado na espessura endometrial nos dois tratamentos. 


\section{INTRODUÇÃO}

Podemos dizer que a menopausa é um evento recente na vida das mulheres, já que apenas nos últimos 200 anos elas passaram a viver o suficiente para atingir a idade de falência ovariana. A média de idade da menopausa nos países ocidentais é de 51 anos, com uma variação de 40-60 anos (EDEN, 1998). Com o crescimento da população idosa, muitas mulheres chegam a passar cerca de 1/3 de suas vidas na pósmenopausa, o que representa sério desafio à saúde pública, na busca de novas alternativas para prevenir e adiar as doenças que possam interferir na qualidade de vida desta população (PALÁCIOS et al., 2005).

A procura por terapias alternativas para o tratamento dos sintomas menopausais vem crescendo muito nos últimos anos, em virtude do aumento de mulheres com contra-indicação para terapia hormonal, e daquelas que preferem tratamentos mais naturais, temerosas dos efeitos colaterais ou pela repercussão de estudos clínicos na área (O’LEARY, 1994; LEWIS et al., 2006).

Alguns estudos epidemiológicos mostram que sintomas como ondas de calor e suores são menos prevalente e de menor intensidade em países orientais (LOCK, 1986; PENOTTI et al., 2003). Além disto, doenças cardiovasculares, osteoporose, câncer de mama, ovário e endométrio, são menos incidentes em países asiáticos (BALK et al., 2002). Desta forma, duas teorias foram levantadas para explicar esta observação. A primeira refere-se a fatores culturais e a segunda, à dieta. ADLERCREUTZ et al. (1992) mostrou que a excreção urinária de fitoestrógenos, como isoflavonas e lignanas, era de 10-100 vezes maior em mulheres que consumiam a dieta japonesa tradicional em comparação com a dieta ocidental. A 
partir desse estudo, a hipótese de que a dieta rica em fitoestrógenos poderia aliviar os sintomas menopausais passou a ser mais investigada.

Fitoestrógenos são compostos presentes nos alimentos que possuem semelhança estrutural com estrógenos e que podem exercer ação estrogênica fraca ou antiestrogênica, dependendo da concentração de estradiol endógeno e do órgão específico envolvido. Entre os principais tipos de fitoestrógenos estão as lignanas encontradas na maioria das plantas, mas em altas concentrações na semente de linhaça, e as isoflavonas, abundantes na soja e derivados (THOMPSON et al., 1991; EDEN, 1998).

A principal lignana presente na semente de linhaça é o diglicosídeo secoisolaresinol (SDG), que precisa ser convertido pela nossa microbiota intestinal em enterodiol e enterolactona, formas biologicamente ativas. Os compostos presentes na soja também precisam ser metabolizados no intestino em daidzeína, genisteína e equol para que tenham efeito (THOMPSON et al., 1991).

Estudos com isoflavonas e lignanas ingeridas sob diferentes formas vêm mostrando resultados inconclusivos dos seus efeitos sobre as ondas de calor. Alguns estudos incluíram mulheres na pré e pós-menopausa, o que pode ter influenciado o efeito estrogênico e antiestrogênico dos fitoestrógenos (ALBERTAZZI et al., 1998; BRZEZINSKI et al., 1997; BURKE et al., 2003; KNIGHT et al., 2001). Outros estudos, utilizando isolados protéicos de soja, tiveram altas taxas de desistência das pacientes (20-24\%) devido aos efeitos colaterais no trato gastro-intestinal (ALBERTAZZI et al., 1998; KNIGHT et al., 2001; KOTSOPOLOUS et al., 2000). Alguns estudos utilizando alimentos como fonte de fitoestrógeno, envolveram a 
substituição de elementos da dieta para manutenção das calorias ingeridas (BRZEZINSKI et al. 1997; ST. GERMAIN et al., 2001).

Nem todos os estudos realizados foram controlados com placebo (WILCOX et al., 1990; LEMAY et al., 2002). Alguns não controlaram a ingestão de fitoestrógenos por outras fontes, o que pode ter gerado alguma interferência (MURKIES et al., 1995; BABER et al., 1999; LEMAY et al., 2002). Outros utilizaram métodos para avaliação das variáveis de desfecho que não haviam sido validados para aquele propósito (BRZEZINSKI et al., 1997; ST. GERMAIN et al., 2001; LEMAY et al., 2002; HAN et al., 2002).

Com relação ao endométrio, estudos biológicos e in vitro com derivados de soja mostraram efeito de estimulação estrogênica em células endometriais (HALE et al., 2002), sugerindo uma possível ação agonista destes compostos nessas células. Apesar destes estudos com animais mostrarem efeito proliferativo da soja sobre o endométrio, poucos verificaram seus efeitos em mulheres menopausadas (UPMALIS et al., 2000; BALK et al., 2002; PENOTTI et al., 2003) e o efeito proliferativo na espessura endometrial.

Finalmente, poucos estudos até agora avaliaram os efeitos do consumo de farinha de linhaça, rica em lignanas, fornecida na forma de um produto (pão), como parte da dieta habitual, para mulheres na pós-menopausa, orientadas a evitar o consumo de outros alimentos fonte de fitoestrógenos.

Desta forma, o objetivo principal deste estudo foi avaliar o efeito do consumo diário de pães feitos com farinha de linhaça, ricos em lignanas, sobre os sintomas climatéricos e espessura endometrial de pacientes na pós-menopausa. 


\section{MATERIAL E MÉTODOS}

\subsection{VARIÁVEIS}

As principais variáveis de desfecho, as ondas de calor e os sintomas climatéricos, foram medidas através do registro diário do número de ondas de calor e do Índice Menopausal de Kupperman (IMK) no início e após 3 meses de intervenção.

O número de ondas de calor e os calores noturnos foram registrados em um diário entregue no início do estudo e recolhido mensalmente. Foram comparadas as médias mensais, calculadas pela soma do número total de ondas de calor/dia, dividido pelo total de dias no mês.

Para avaliação dos sintomas menopausais utilizou-se o Índice Menopausal de Kupperman (IMK), que vem sendo utilizado nos últimos 50 anos como medida para avaliação dos principais desconfortos associados à menopausa. Este índice é composto por 11 itens (ondas de calor, parestesia, insônia, nervosismo, depressão, vertigem, fadiga, artralgia, palpitação, cefaléia e zumbido) avaliados pela escala Likert $(0=$ ausente; $1=$ leve; $2=$ moderado; $3=$ intenso $)$ dependendo da intensidade. Cada escore é multiplicado por um fator definido, de acordo com a contribuição do sintoma para o índice. A pontuação varia de 0 a 51 (leve< 20; moderado 20-30; intenso>30). As avaliações clínicas do IMK foram realizadas sempre pelo mesmo pesquisador no início e ao final de 3 meses (Anexo 2).

Os exames de sangue foram realizados no Hospital das Clínicas da Faculdade de Medicina da Universidade de São Paulo (USP), pela divisão do Laboratório Central. Foram realizados exames bioquímicos para avaliação plasmáticas do perfil 
lipídico (colesterol total, HDL, LDL, VLDL, triglicérides) e dos seguintes hormônios: estradiol, FSH, TSH, T4 livre.

A espessura endometrial foi avaliada em parceria com o Instituto de Radiologia do Hospital das Clínicas, da FM-USP, sempre pelo mesmo observador, por via supra-púbica e transvaginal, sendo avaliadas também sua homogeneidade e linearidade. A medida da espessura do endométrio foi feita na sua maior porção no corte longitudinal do útero, sendo realizadas pelo menos três medições. Os equipamentos de ultra-sonografia utilizados foram: Phillips, modelo HDI 5000 SonoCT, com transdutor multifreqüencial de $2-5 \mathrm{MHz}$ e transdutor endovaginal multifreqüencial de 5-9 $\mathrm{MHz}$ e GE, modelo Voluson 730, com transdutor convexo multifreqüencial de 2-5 MHz e transdutor endovaginal de 4-8 MHz.

A dieta das pacientes foi avaliada através de quatro recordatórios de 24 horas, 2 antes do tratamento e 2 ao final, em diferentes dias da semana. Estas informações foram analisadas pelo Programa de Apoio à Nutrição (Nutwin - versão 1.5.2.51, de 2005), da Universidade Federal de São Paulo (Unifesp). As pacientes selecionadas foram orientadas a evitar o consumo de linhaça, soja e seus derivados durante o período de intervenção, através de uma lista com os principais alimentos.

\subsection{POPULAÇÃo}

As mulheres que participaram deste estudo foram recrutadas entre as pacientes atendidas na Casa do Climatério/Fundação Zerbini e no Centro de Saúde Escola Geraldo de Paula Souza da Faculdade de Saúde Pública da USP, de abril de 2005 a julho de 2006. O critérios de inclusão foram amenorréia há pelo menos 1 ano, estradiol $<20$ pg/mL e FSH > 39 IU/L, Índice Menopausal de Kupperman (IMK) de 
moderado a severo (20-51) e pelo menos duas ondas de calor/dia. Os critérios de exclusão foram: uso de terapia hormonal nos últimos 3 meses, uso de antibiótico no último mês, uso de antidepressivos ou suplementos a base de fitoestrógeno, hipertensão não controlada, distúrbio na tireóide, diabetes mellitus e alergia a qualquer ingrediente dos pães.

Todas as pacientes selecionadas assinaram o Termo de Consentimento aprovado pelo Comitê de Ética em Pesquisa (COEP) da Faculdade de Saúde Pública da Universidade de São Paulo, de acordo com os requisitos da Resolução CNS/196/96, sob protocolo de pesquisa $\mathrm{n}^{\mathbf{0}}$ 1019, 2003.

\subsection{PRODUTO}

Para intervenção foram desenvolvidos dois tipos de pães isocalóricos, com conteúdo de lipídeos, fibras e aparência similares. O primeiro deles, com farinha de linhaça e o segundo (controle), com farelo de trigo e cevada torrada para ajuste do conteúdo de fibras e coloração. Um único lote da farinha de linhaça foi fornecido pela empresa Pazze Ltda. e armazenado sob refrigeração $\left(<8^{\circ} \mathrm{C}\right)$ durante o todo período do estudo. Para maximizar o conteúdo de lignanas (presente na parte fibra da semente) no pão de estudo e para ajuste do conteúdo de lipídeos nos pães, utilizou-se uma farinha de linhaça parcialmente desengordurada (redução de $44 \%$ no teor de lipídeos). Cada porção diária fornecia o equivalente a $25 \mathrm{~g}$ da semente integral e 46 mg de SDG (precursores de lignanas mamíferas), o diglicosídio secoisolaresinol. No pão controle, os valores de SDG foram insignificantes. O conteúdo de macronutrientes dos produtos de intervenção está apresentado na Tabela 1. 
Tabela 1 - Conteúdo de macronutrientes dos pães.

\begin{tabular}{lcc}
\hline & Pão de Linhaça & Pão Controle \\
\hline Energia, Kcal & 210 & 230 \\
Proteínas, g & 15,4 & 8,6 \\
Lipídeos, g & 1,4 & 1,6 \\
Carboidratos, g & 33,2 & 44 \\
Cinzas, g & 1,5 & 1,75 \\
Água, g & 37,3 & 33,2 \\
Fibras, g & 11,2 & 10,9 \\
\hline
\end{tabular}

*valores calculados para $100 \mathrm{~g}$ de produto.

Em termos de sabor e aparência, os produtos ficaram bastante semelhantes, não sendo diferenciados por provadores treinados. De toda forma, foram utilizadas embalagens douradas e opacas. De acordo com os valores apresentados, o conteúdo de fibras e lipídeos mostrou-se bastante similar nos dois produtos.

Toda produção foi realizada, quinzenalmente, na padaria industrial do Instituto de Desenvolvimento da Panificação e Confeitaria (IDPC - São Paulo).

\subsection{INTERVENÇÃO E RANDOMIZAÇÃO}

Foi realizado um estudo clínico duplo-cego, randomizado, com controle placebo e duração de 3 meses. As pacientes selecionadas passaram em consulta prévia com ginecologistas que avaliaram as condições gerais de saúde, o histórico de doenças e o IMK. Neste mesmo momento passaram por avaliação de peso e altura para cálculo do IMC $\left(\mathrm{Kg} / \mathrm{m}^{2}\right)$, avaliação de consumo e foi aferida a pressão arterial. Uma semana antes do início do estudo as pacientes receberam um diário para marcar o número de ondas de calor (baseline). Após esta avaliação inicial, as pacientes realizaram os exames de sangue e ultra-som. A randomização das pacientes foi realizada por uma funcionária Departamento de Nutrição da USP, através de uma lista gerada por computador. A mesma recebia as caixas com os pães acondicionados 
em embalagens opacas e era responsável pela separação dos produtos, de acordo com a randomização. Desta forma, pacientes, médicos e a pesquisadora responsável permaneceram cegos até que a última paciente fizesse seu último exame. Cada paciente recebia os pães a cada 15 dias, embalados individualmente ( 2 fatias), e foram orientadas a mantê-los congelados até o dia de consumo, no horário e forma desejada, como parte de sua dieta habitual. As pacientes foram orientadas a marcar o número de ondas de calor, sem intensidade ou duração, em um diário durante todo período. A cada entrega dos pães, as pacientes eram questionadas sobre eventuais efeitos colaterais e sobre o consumo de alimentos ricos em isoflavonas e lignanas. A adesão ao consumo foi verificada através dos diários. Ao final de 12 semanas as pacientes retornaram a Casa do Climatério e repetiram todas os exames e avaliações iniciais. Para verificar a aceitabilidade e a falta de capacidade para identificar os pães consumidos, as pacientes foram questionadas sobre a intenção de continuar comendo o produto e sobre qual pão elas acreditavam ter consumido.

\subsection{ANÁLISES ESTATÍSTICAS}

A análise descritiva das variáveis quantitativas mostrou que todas apresentaram distribuição normal, com exceção do estradiol e espessura endometrial (teste de Kolmogorov-Smirnov). A análise comparativa entre os grupos foi feita pelo teste t-Student e o de Mann-Whitney para as variáveis que não apresentaram aderência à distribuição normal. O teste de Wilcoxon foi utilizado para comparar cada grupo, antes e após 3 meses. O nível de significância foi fixado em 5\%. As análises foram realizadas no programa SPSS 12.0. 


\section{RESULTADOS}

Ao final do estudo o número de pacientes selecionadas foi de 38 , sendo 20 no grupo de estudo e 18 no grupo controle. Das mulheres selecionadas, apenas uma do grupo placebo não concluiu o estudo, abandonando-o no primeiro mês, por motivo pessoal. Os efeitos colaterais relatados a pesquisadora durante a intervenção foram: o maior fluxo intestinal, flatulência e sensação de maior saciedade, que podem ser explicados pelo elevado conteúdo de fibras dietéticas nos dois pães. O consumo dos pães foi verificado através dos diários. Os pães foram bem aceitos, com uma média de consumo de $94 \%$ nos dois grupos. Duas pacientes do grupo placebo relataram certa fadiga ao consumir os pães todos os dias, a partir da metade da intervenção. Por serem bastante similares em termos de aparência (coloração marrom) e rico em fibras, ao final do estudo, quase todas as pacientes acreditavam ter consumido o pão de linhaça, mesmo aquelas do grupo placebo.

Com relação às características gerais (peso, altura, idade, meses na pósmenopausa), pode-se observar na Tabela 2 que não houve diferença estatística significativa entre os dois grupos de tratamento, no pré-tratamento. 
Tabela 2 - Características gerais no pré-tratamento.

\begin{tabular}{lllcl}
\hline & Grupo & $\mathrm{N}$ & Média $(\mathrm{dp})$ & $\mathrm{P}$ \\
\hline Peso $(\mathrm{Kg})$ & Linhaça & 20 & $65,35(10,31)$ & \multirow{2}{*}{0,706} \\
& Controle & 18 & $63,87(13,31)$ & \\
\hline Altura $(\mathrm{m})$ & Linhaça & 20 & $1,57(0,07)$ & 0,710 \\
& Controle & 18 & $1,56(0,06)$ & \\
\hline \multirow{2}{*}{$\mathrm{MC}\left(\mathrm{Kg} / \mathrm{m}^{2}\right)$} & Linhaça & 20 & $26,44(3,61)$ & \multirow{2}{*}{0,818} \\
& Controle & 18 & $26,11(5,01)$ & \\
\hline \multirow{2}{*}{ meses no climatério } & Linhaça & 20 & $45,30(26,98)$ & 0,748 \\
& Controle & 18 & $42,11(32,99)$ & \\
\hline Idade (anos) & Linhaça & 20 & $52,00(2,88)$ & \multirow{2}{*}{0,580} \\
& Controle & 18 & $52,66(4,24)$ & \\
\hline
\end{tabular}

A Tabela 3 mostra médias e desvios-padrão para os dados clínicos no prétratamento em ambos grupos. A média inicial do Índice Menopausal de Kupperman foi similar entre os grupos $(\mathrm{P}=0,97)$, conforme critério de inclusão (acima de 20$)$. $\mathrm{O}$ mesmo pode ser observado com a frequiência média inicial das ondas de calor, que foi de 8,5/dia nos dois grupos, não apresentando diferença estatística significativa.

Entre as variáveis comparadas no pré-tratamento, o perfil lipídico (colesterol total, frações e triglicerídeos) apresentou diferença estatística significativa entre os dois grupos (Tabela 3). O grupo linhaça apresentou uma maior média para colesterol total, frações de LDL e VLDL e os triglícerídeos e fração HDL menor do que o grupo controle. Em ambos grupos, a média inicial do colesterol total ficou acima do valor máximo recomendado $(200 \mathrm{mg} / \mathrm{dL})$, bem como a média da fração de LDLcolesterol no grupo linhaça, que ficou acima de $130 \mathrm{mg} / \mathrm{dL}$.

Com relação aos hormônios tireoidianos, pôde-se observar que todas apresentaram dosagens de TSH e $\mathrm{T}_{4}$ livre dentro do esperado. Este controle é importante, já que distúrbios na glândula tireóide podem interferir nos sintomas 
vasomotores, como nas ondas de calor. Todas as pacientes apresentaram valores de estradiol inferior a $20 \mathrm{pg} / \mathrm{mL}$ e FSH acima de $39 \mathrm{IU} / \mathrm{L}$, característicos da fase de pósmenopausa, não havendo diferença estatística significativa entre grupos.

Tabela 3 - Dados clínicos no pré-tratamento por grupo.

\begin{tabular}{|c|c|c|c|c|}
\hline & Grupo & $\mathrm{N}$ & Média (dp) & $\mathrm{P}$ \\
\hline \multirow[t]{2}{*}{ IMK } & Linhaça & 20 & $20,9(7,86)$ & \multirow{2}{*}{0,970} \\
\hline & Controle & 18 & $21,00(8,58)$ & \\
\hline \multirow[t]{2}{*}{ Ondas de calor(n) } & Linhaça & 20 & $8,5(4,33)$ & \multirow{2}{*}{1,000} \\
\hline & Controle & 16 & $8,5(5,01)$ & \\
\hline \multirow[t]{2}{*}{ Col.total (mg/dL) } & Linhaça & 18 & $233,11(33,69)$ & \multirow{2}{*}{$0,015^{\prime}$} \\
\hline & Controle & 17 & $202,76(36,06)$ & \\
\hline \multirow[t]{2}{*}{$\mathrm{HDL}(\mathrm{mg} / \mathrm{dL})$} & Linhaça & 18 & $62,00(12,13)$ & \multirow{2}{*}{$0,043^{\prime}$} \\
\hline & Controle & 17 & $71,94(15,61)$ & \\
\hline \multirow[t]{2}{*}{$\mathrm{LDL}(\mathrm{mg} / \mathrm{dL})$} & Linhaça & 18 & $147,94(34,41)$ & \multirow{2}{*}{0,007} \\
\hline & Controle & 17 & $113,47(34,41)$ & \\
\hline \multirow[t]{2}{*}{ VLDL (mg/dL) } & Linhaça & 18 & $23,16(9,53)$ & \multirow{2}{*}{$0,073^{\star}$} \\
\hline & Controle & 17 & $17,35(8,99)$ & \\
\hline \multirow[t]{2}{*}{ Triglicérides (mg/dL) } & Linhaça & 18 & $131,61(70,36)$ & \multirow{2}{*}{$0,042^{*}$} \\
\hline & Controle & 16 & $87,62(46,62)$ & \\
\hline \multirow[t]{2}{*}{ Estradiol (pg/mL) } & Linhaça & 20 & $14,15(2,99)$ & \multirow{2}{*}{0,850} \\
\hline & Controle & 18 & $15,06(4,77)$ & \\
\hline \multirow[t]{2}{*}{ FSH (IU/L) } & Linhaça & 20 & $80,63(21,79)$ & \multirow{2}{*}{0,227} \\
\hline & Controle & 18 & $91,21(30,93)$ & \\
\hline \multirow[t]{2}{*}{ TSH (uU/mL) } & Linhaça & 20 & $1,69(0,59)$ & \multirow{2}{*}{0,216} \\
\hline & Controle & 18 & $1,42(0,75)$ & \\
\hline \multirow[t]{2}{*}{ T4 livre (ng/dL) } & Linhaça & 20 & $1,05(0,16)$ & \multirow{2}{*}{0,313} \\
\hline & Controle & 18 & $1,01(0,10)$ & \\
\hline \multirow{2}{*}{$\begin{array}{l}\text { Espessura endometrial } \\
(\mathrm{mm})\end{array}$} & Linhaça & 17 & $2,41(0,75)$ & \multirow{2}{*}{0,450} \\
\hline & Controle & 13 & $3,02(1,61)$ & \\
\hline
\end{tabular}

$* p<0,05, d p=$ desvio padrão

A Tabela 4 mostra a média de macronutrientes ingerida por cada grupo de tratamento. Nenhuma diferença estatística significativa foi observada nos grupos ou entre grupos no momento, tanto no pré como no pós-tratamento (t0 e t3). 
Tabela 4 - Consumo médio de macronutrientes no pré e pós-tratamento.

\begin{tabular}{lccc|ccc}
\hline & \multicolumn{3}{c|}{ Linhaça $(\mathrm{n}=20)$} & \multicolumn{3}{c}{ Controle $(\mathrm{n}=18)$} \\
\hline & $\mathrm{t} 0$ & $\mathrm{t} 3$ & $\mathrm{P}$ & t0 & t3 & $\mathrm{P}$ \\
\hline Energia, Kcal & 1204,3 & 1272,6 & 0,445 & 1289,8 & 1282,4 & 0,935 \\
Proteínas, g & 54,5 & 60,4 & 0,313 & 69,4 & 72,9 & 0,667 \\
Lipídeos, g & 40,3 & 40,6 & 0,951 & 41,5 & 40,3 & 0,805 \\
Carboidratos, g & 162,14 & 168,9 & 0,552 & 167,7 & 160,8 & 0,620 \\
Fibras, g & 17,35 & 19,6 & 0,367 & 16,7 & 16,8 & 0,990 \\
\hline
\end{tabular}

Estes valores de controle da dieta são importantes para demonstrar que, durante o período de suplementação com os pães, não houve alteração estatística significativa na ingestão calórica nem no conteúdo dos macronutrientes, conforme solicitado às pacientes.

As principais variáveis clínicas avaliadas foram comparadas, antes e após a intervenção, e estão relacionadas na Tabela 5.

Tabela 5 - Variação no pré e pós-tratamento em cada grupo de estudo.

\begin{tabular}{l|llll|lll}
\hline & \multicolumn{3}{|c|}{ Linhaça (n=20) } & \multicolumn{3}{c}{ Controle (n=18) } \\
\hline & \multicolumn{1}{|c|}{$\mathrm{t} 0(\mathrm{dp})$} & $\mathrm{t} 3(\mathrm{dp})$ & $\mathrm{P}$ & $\mathrm{t} 0(\mathrm{dp})$ & $\mathrm{t} 3(\mathrm{dp})$ & $\mathrm{P}$ \\
\hline IMK & $20,9(7,86)$ & $12,55(6,69)$ & $<0,001^{*}$ & $21(8,58)$ & $12,94(5,66)$ & $<0,001^{*}$ \\
Ondas (n/dia no mês) & $8,5(4,33)$ & $5,16(3,92)$ & $<0,001^{*}$ & $8,5(5,01)$ & $4,01(2,41)$ & $0,002^{*}$ \\
Esp. endometrial (mm) & $2,41(0,75)$ & $2,89(0,78)$ & 0,055 & $3,02(3,02)$ & $3,56(2,78)$ & 0,533 \\
Col. Total (mg/dL) & $233,11(33,69)$ & $229,67(43,47)$ & 0,665 & $200,37(35,82)$ & $199,12(32,52)$ & 0,797 \\
HDL (mg/dL) & $62(12,13)$ & $61,28(9,36)$ & 0,707 & $71,75(16,11)$ & $66,75(16,00)$ & $0,041^{*}$ \\
LDL (mg/dL) & $147,94(34,41)$ & $141,83(39,75)$ & 0,449 & $111,06(35,70)$ & $111,81(32,97)$ & 0,881 \\
Triglicérides (mg/dL) & $131,61(70,36)$ & $148,6(89,75)$ & 0,223 & $88,73(48,04)$ & $99,13(45,04)$ & 0,115 \\
Estradiol (pg/mL) & $14,15(2,99)$ & $14,5(3,27)$ & 0,44 & $15,18(4,89)$ & $14,51(2,58)$ & 0,52 \\
FSH (IU/L) & $80,63(21,79)$ & $79,66(17,45)$ & 0,707 & $90,1(31,51)$ & $83,96(29,95)$ & $0,031^{*}$ \\
TSH (uU/mL) & $1,69(0,56)$ & $1,61(0,59)$ & 0,583 & $1,43(0,77)$ & $1,63(0,80)$ & 0,228 \\
T4 livre (ng/dL) & $1,05(0,16)$ & $1,04(0,12)$ & 0,494 & $1(0,11)$ & $1,03(0,13)$ & 0,368 \\
\hline
\end{tabular}

$* p<0,05 ; \mathrm{dp}=$ desvio padrão 
O grupo controle apresentou uma diminuição estatisticamente significativa nos valores de HDL-colesterol e do hormônio folículo estimulante (FSH), após intervenção. Apesar de alguns ensaios biológicos e clínicos (LUCAS et al., 2004; ARJMANDI et al., 1998) com a semente de linhaça demonstrarem sua capacidade em reduzir o colesterol total e o LDL, o mesmo não pôde ser observado nesta intervenção, onde estes valores não apresentaram variação estatística significativa durante o estudo. Outros estudos clínicos, com mulheres hipercolesterolêmicas na menopausa (LEMAY et al., 2002; DODIN et al., 2005), confirmam estes resultados, não encontrando diferença estatística significativa nos níveis de colesterol total e frações após o consumo de $40 \mathrm{~g} /$ dia de linhaça. Apesar do perfil lipídico não ter sido uma variável de desfecho, coincidentemente, o grupo de estudo apresentou uma média inicial elevada para estes parâmetros. No entanto, nenhuma alteração nestas variáveis foi identificada após 3 meses de intervenção com linhaça parcialmente desengordurada.

Os dois grupos apresentaram uma diminuição estatística significativa nos sintomas climatéricos (IMK) e nas ondas de calor. Estudos randomizados com placebo mostram que o efeito placebo sobre as ondas de calor varia em média de 20$30 \%$ no número e severidade, nas 4 primeiras semanas (STEARNS et al., 2002). A Tabela 6 mostra a evolução média do número de ondas de calor, em cada mês, dentro dos grupos. Duas pacientes do grupo controle que participaram do estudo não tiveram seus números de ondas avaliados, uma por ser analfabeta e a outra por problemas no preenchimento do diário. Como pode-se observar, a partir do primeiro mês já houve redução estatística significativa no número médio de ondas nas pacientes dos 2 grupos. 
A redução nas ondas de calor no grupo de estudo foi maior até o final do segundo mês, voltando a aumentar a partir do terceiro. Com um maior tempo de intervenção, provavelmente, verificaríamos efeito similar no grupo placebo. Segundo MOM et al. (2006), o efeito placebo sobre as ondas de calor no primeiro mês de tratamento, atinge cerca de $25 \%$ das pacientes, com uma melhora de pelo menos $50 \%$ nos sintomas. A melhora nas ondas de calor em mulheres tomando placebo foi observada em estudos que também utilizaram diários, como medida da freqüência e severidade destes sintomas. Tais estudos mostram a importância de ensaios duplocegos, controlados com placebo, para testar a eficácia de um tratamento sobre estes sintomas.

Tabela 6 - Média diária ondas de calor a cada mês nos 2 grupos.

\begin{tabular}{rcccc}
\hline & T0 & T1 & T2 & T3 \\
\hline Grupo linhaça & & & & \\
No. pacientes & 20 & 20 & 20 & 20 \\
No. Ondas (média) & 8,50 & 7,20 & 4,94 & 5,17 \\
P & & $<0,001$ & $<0,001$ & $<0,001$ \\
Grupo controle & & & & \\
No. pacientes & 16 & 16 & 16 & 16 \\
No. Ondas (média) & 8,50 & 6,95 & 5,34 & 4,01 \\
P & & 0,002 & 0,002 & 0,002 \\
\hline
\end{tabular}

Os gráficos 1 e 2 abaixo ilustram o comportamento dos dois grupos de estudo, com relação ao IMK e as ondas de calor, respectivamente. Em ambos é possível visualizar que não houve diferença entre os dois grupos no momento inicial e final do estudo. 


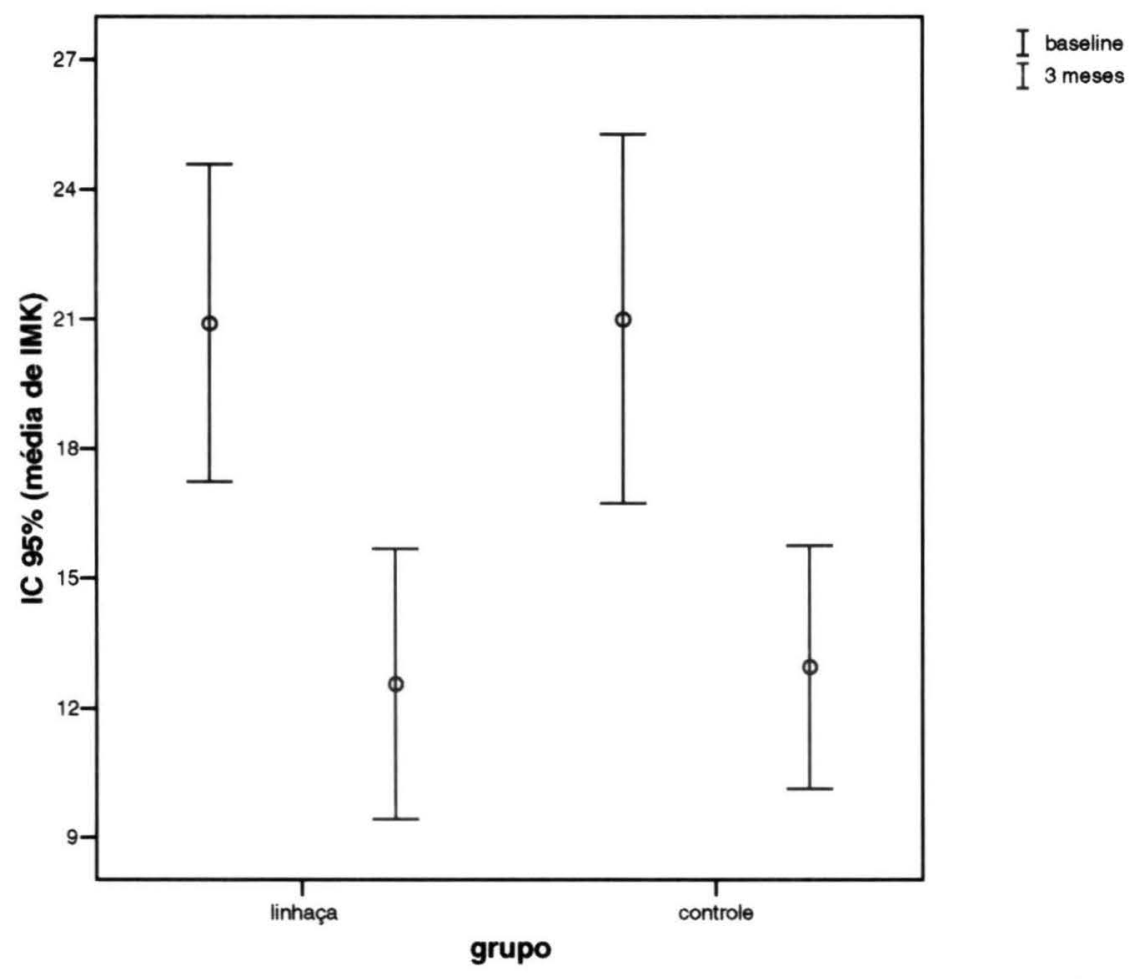

Gráfico 1 - Média e desvio padrão dos valores de IMK por grupo.

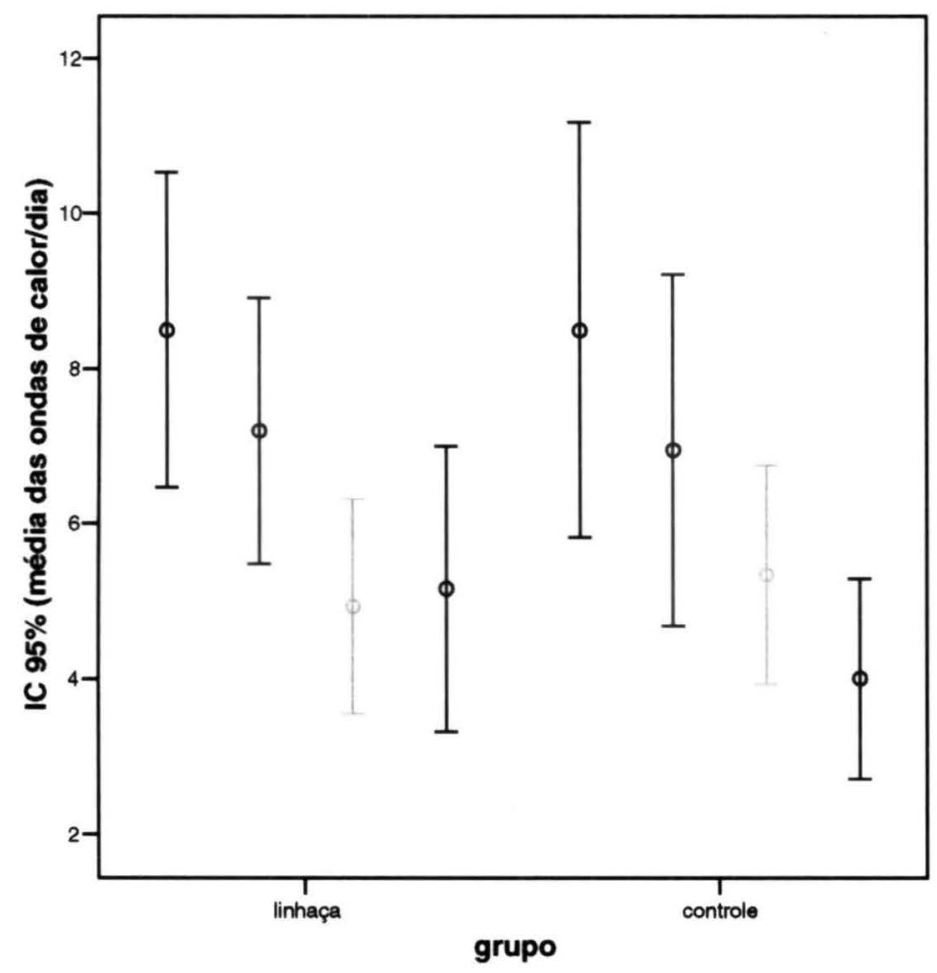

I baseline

I média diária mês 1

média diária mês 2

I média diária mês 3

Gráfico 2 - Média e desvio padrão do número médio diário de ondas em cada mês. 


\section{DISCUSSÃo}

Como podemos observar nos gráficos, os dois grupos de estudo apresentaram comportamentos bastante similares durante o período de intervenção, não havendo diferença estaticamente significativa entre eles.

Sintomas menopausais são bastante freqüentes e provocam impacto negativo sobre a qualidade de vida de muitas mulheres. Desta forma, vários tipos de tratamentos alternativos vêm sendo investigados, mas nenhum demonstrou a mesma eficácia dos esteróides sexuais. As recentes discussões em torno do uso da terapia hormonal mostram que médicos e pacientes devem considerar, no momento da decisão do tratamento, não somente o alívio dos sintomas vasomotores, mas também os riscos para o desenvolvimento de doenças cardiovasculares, câncer de mama, osteoporose e tromboembolismo.

Existem poucos estudos avaliando os efeitos dos fitoestrógenos nos sintomas climatéricos de mulheres na pós-menopausa. Este estudo, utilizando um alimento natural rico em lignanas e outro controle, não encontrou diferença estatística significativa nos sintomas, entre os 2 grupos, após 12 semanas de tratamento. Em ambos, as pacientes apresentaram redução significativa no número de ondas e no IMK em relação ao início do tratamento, mas não houve diferença entre os grupos ao final do tratamento. Esta melhora pode estar em parte relacionada a diminuição na disposição em marcar corretamente os sintomas no diário com o passar do tempo. No entanto, todas as pacientes envolvidas no estudo demonstraram uma boa adesão durante todo o período de intervenção, confirmada pela assiduidade quinzenal das visitas. Além disto, sabe-se que, em estudos com mulheres na menopausa com 
queixas para ondas de calor, uma elevada taxa de desistência é observada quando não existe melhora real dos sintomas. Tal fato não foi verificado no presente estudo, o que pode ser indicativo da real melhora nos sintomas destas pacientes.

Alguns estudos que reportam melhora nos sintomas vasomotores avaliaram no diário, além do número de fogachos, a intensidade destes sintomas (LEWIS et al., 2006). Neste ensaio a intensidade das ondas foi avaliada somente no início e ao final do tratamento, durante as avaliações do IMK.

Apesar dos pães fornecerem quantidade elevada de lignanas vegetais (46 $\mathrm{mg} / \mathrm{dia}$ ), seria interessante confirmar, através dos exames de urina, o aumento na excreção de enterodiol e enterolactonas. Para que estes metabólitos sejam excretados é necessária transformação das lignanas vegetais em lignanas mamíferas através das bactérias do trato intestinal. LEWIS et al. (2006) forneceu uma quantidade equivalente $(40 \mathrm{mg})$ de lignanas na forma de "muffins" e pôde verificar um aumento de 8 vezes no total destes metabólitos.

\section{CONCLUSÃO}

A administração de $46 \mathrm{mg} /$ dia de lignanas na forma de pães não é mais efetiva que o placebo na redução das ondas de calor e do IMK. Nenhum efeito foi verificado na espessura endometrial nos dois tratamentos. Neste caso, pode-se concluir que os fitoestrógenos provenientes da linhaça não afetaram de forma significativa os sintomas menopausais quando comparados com placebo. Este estudo, no entanto, confirma a importância do grupo placebo para se comparar os efeitos de outros tratamentos sobre estes sintomas. 


\section{BIBLIOGRAFIA}

1. ADLERCREUTZ, H.; MOUSAVI, Y.; CLARK, J. et al. Dietary phytoestrogens and cancer: in vitro and in vivo studies. J Steroid Biochem Mol Biol, v. 41, p. 331$337,1992$.

2. ALBERTAZZI, P.; PANSINI, F.; BONACCORSI, G. et al. The effect of dietary soy supplementation on hot flushes. Obstet gynecol, v. 91, p. 6-11, 1998.

3. ARJMANDI, B. H.; KHAN, D. A.; JUMA, S.; DRUM, M. L. et al. Whole flaxseed consumption lowers serum LDL-cholesterol and lipoprotein(a) concentrations in postmenopausal women Nutrition Research, v. 18, p. 1203-1214, 1998.

4. BABER, R.; TEMPLEMAN, C.; MORTON, T.; KELLY, G.; WEST, L. Randomized placebo-controlled trial of an isoflavone supplement and menopausal symptoms in women. Climacteric, v. 2, p. 85-92, 1999

5. BALK, J. L. et al. A pilot study of the effects of phytoestrogen supplementation on postmenopausal endometrium. J. Soc. Gynecol. Invesg., v. 9, p. 238-42, 2002.

6. BRZEZINSKIN, A.; ADLERCREUTZ, H.; SHAOUL, R, et al. Short-term effects of phytoestrogen-rich diet on post menopausal women. Menopause, v. 4, p. 89-94, 1997.

7. BURKE, G.; LEGAULT, C.; ANTHONY, M. et al. Soy protein and isoflavone effects on vasomotor symptoms in peri- and postmenopausal women: the Soy Estrogen Alternative Study. Menopause, v. 10, p. 147-153, 2003.

8. DODIN, S.; LEMAY, A.; JACQUES, H.; LEGARE, F.; FOREST, J. C.; MASSE, B. The effects of flaxseed dietary supplement on lipid profile, bone mineral density, and symptoms in menopausal women: a randomized, double-blind, wheat germ placebo-controlled clinical trial. J. Clin. Endocrinol. Metab., v. 90, p 1390-1397, 2005 .

9. EDEN, J. Phytoestrogens and menopause. Clinical endocrinology and metabolism, v.12, p.581-587, 1998.

10. HALE, G. E.; HUGHES, C. L.; CLINE, J. M. Endometrial cancer: hormonal factors, the perimenopausal "window of risk", and isoflavones. J Clin Endocrinol Metab., v.87, p. 3-15, 2002.

11. HAN, K. K.; SOARES, J. M. JR.; HAIDAR, M. A.; DE LIMA, G. R.; BARACAT, E. C. Benefits of soy isoflavone therapeutic regimen on menopausal symptoms. Obstet Gynecol, v. 99, p.389-394, 2002. 
12. KNIGHT D, HOWES J, EDEN J, HOWES L. Effects on menopausal symptoms and acceptability of isoflavone-containing soy powder dietary supplementation. Climacteric, v. 4, p. 13-18, 2001.

13. KOTSOPOLOUS D, DALAIS F, LIANG Y, MCGRATH B, TEEDE H. The effects of soy protein containing phytoestrogens on menopausal symptoms in postmenopausal women. Climacteric, v. 3, p. 161-167, 2000.

14. EMAY A, DODIN S, KADRI N, JACQUES H, FOREST JC. Flaxseed dietary supplement versus hormone replacement therapy in hypercholesterolemic menopausal women. Obstet. Gynecol., v. 100, p. 495-504, 2002.

15. LEWIS, JE, et al. A randomize controlled trial of the effect of dietary soy and flaxseed muffins on quality of life and hot flushes during menopause. Menopause, $v$. 13, p. 631-642, 2006.

16. LOCK M. Ambiguites of aging: Japanese experience and perceptions of menopause. Culture maedicine and psychiatry, v. 10, p. 23-46, 1986.

17. LUCAS EA, STANLEY A. et al. Flaxseed reduces plasma cholesterol and atherosclerotic lesion formation in ovariectomized Golden Syrian hamsters. Atherosclerosis, v. 173, p. 223-229, 2004.

18. MOM CH, BUIJS C, WILLEMSE PHB, MOURITS MJE, DE VRIES EGE. Hot flushes in breast cancer patients. Critical reviews in oncology/hematology, v. 57, p. 63-77, 2006.

19. MURKIES AL, LOMBARD C, STRAUSS BJ, et al. Dietary flour supplementation decreases post-menopausal hot flushes: effect of soy and wheat, Maturitas, v. 21, p. 189-195, 1995.

20. NAMS - North American Menopause Society, Treatment of menopauseassociated vasomotor symptoms: position statement of The North American Menopause Society, Menopause v. 11: p. 11-33, 2004.

21. O'LEARY C. Why women choose not to take hormone therapy. In: Berg, G., Hammar, M. The Modern Management of Menopause. Carnforth: England: Pathernon Publishing, 1994. p. 525-532.

22. PALACIOS S, SANCHEZ BR, FORTEZA A. The importance of preventive health care in postmenopausal women. Maturitas, v. 52, p. 53-60, 2005.

23. PENOTTI M, FABIO E, MODENA AB, RINALDI M, OMODEI U, VIGANO $P$. Effect of soy-derived isoflavones on hot flushes, endometrial thickness, and the pulsatility index of the uterine and cerebral arteries. Fertil. Steril., v. 79, p. 1112$1117,2003$.

24. STEARNS V,. ULLMER L, LOPEZ JF, et al. Hot flushes, Lancet, v. 360, p. 1851-1861, 2002. 
25. ST GERMAIN A, PETERSON CT, ROBINSON JG, ALEKEL DL. Isoflavonerich or isoflavone-poor soy protein does not reduce menopausal symptoms during 24 weeks of treatment. Menopause, v. 8, p. 17-26, 2001.

26. TICE J, ETTINGER B, ENSRUD K, WALLACE R, BLACKWELL T, CUMMINGS S. Phytoestrogen supplements for the treatment of hot flashes: the isoflavone clover extract (ICE) study. A randomized control trial. JAMA, v. 290, p. 207-214, 2003.

27. THOMPSON LU, ROBB P, SERRAINO M, CHEUNG F. Mammalian lignan production from various foods. Nutr. Cancer, v. 16, p. 43-52, 1991.

28. UPMALIS DH, LOBO R, BRADLEY L, WARREN M, et al. Vasomotor symptom relief by soy isoflavone extract tablets in postmenopausal women: a multicenter, double-blind, randomized, placebo-controlled study. Menopause, v. 7, p. 236-242, 2000.

29. WILCOX G, WAHIQUIST ML, et al. Oestrogenic effects of plant food in postmenopausal women. British Medical Journal, v. 301, p. 905-906, 1990. 


\section{CONSIDERAÇÕES FINAIS:}

$\mathrm{O}$ presente trabalho atingiu o objetivo de produzir um produto rico em lignanas, a partir do uso de uma farinha de linhaça parcialmente desengordurada.

Verificou-se que os componentes ativos da semente, como o ácido graxo $\alpha$ linolênico e as lignanas vegetais são estáveis ao processamento térmico e estocagem.

O estudo clínico demonstrou que o consumo médio de $25 \mathrm{~g}$ de linhaça/dia (46 mg de lignanas) não foi suficiente para se verificar melhora nas ondas de calor e no IMK, além do efeito placebo.

É importante observar a ocorrência de aumento na excreção de lignanas nas urinas das pacientes do grupo de estudo para confirmar o consumo dos produtos fornecidos e verificar a capacidade de metabolizar estes compostos, dado a variabilidade na conversão de lignanas vegetais. Esta é uma continuação natural deste trabalho e sua concentração será verificada nas urinas destas pacientes após instalação do equipamento CG-MS, no Laboratório de Bioquímica e Propriedades Funcionais dos Alimentos.

Locais onde a assistência à saúde é deficiente, como no Brasil, verificam-se um maior efeito "placebo" nas intervenções clínicas realizadas. De toda forma, este fato demonstra a real importância de modelos duplo-cegos, controlados com placebo, e randomizados em ensaios clínicos, como este.

Como estudos epidemiológicos sugerem associação entre dieta rica em fitoestrógenos e menor incidência de ondas de calor e certas doenças crônicas, estudos futuros deverão testar um alimento convencional, composto por uma mistura 
destes compostos, reunindo isoflavonas e lignanas, em quantidades usualmente consumidas nos países orientais.

Estudos como este, essencialmente multidisciplinares, como a própria saúde pública, exigem o envolvimento de grande número de colaboradores, sem os quais este trabalho não teria sido possível. 